\title{
A Method for Determining "Allowable Residual Contamination Levels" of Radionuclide Mixtures in Soil
}

\author{
B. A. Napier
}

May 1982

Prepared for the U.S. Department of Energy under Contract DE-AC06-76RLO 1830

Pacific Northwest Laboratory Operated for the U.S. Department of Energy by Battelle Memorial Institute 


\title{
DISCLAIMER
}

This report was prepared as an account of work sponsored by an agency of the United States Government. Neither the United States Government nor any agency thereof, nor any of their employees, makes any warranty, express or implied, or assumes any legal liability or responsibility for the accuracy, completeness, or usefulness of any information, apparatus, product, or process disclosed, or represents that its use would not infringe privately owned rights. Reference herein to any specific commercial product, process, or service by trade name, trademark, manufacturer, or otherwise, does not necessarily constitute or imply its endorsement, recommendation, or favoring by the United States Government or any agency thereof. The views and opinions of authors expressed herein do not necessarily state or reflect those of the United States Government or any agency thereof.

\author{
PACIFIC NORTHWEST LABORATORY \\ operated by \\ BATTELLE \\ for the \\ UNITED STATES DEPARTMENT OF ENERGY \\ under Contract DE-AC06-76RLO 1830
}

\begin{tabular}{|c|c|}
\hline \multicolumn{2}{|c|}{ Printed in the United States of Ameris } \\
\hline \multicolumn{2}{|c|}{ Available from } \\
\hline \multicolumn{2}{|c|}{ National Technical Information Servic } \\
\hline \multicolumn{2}{|c|}{ United States Department of Commerc } \\
\hline 5285 & \\
\hline \multicolumn{2}{|c|}{ Springfield, Virginia 22151} \\
\hline \multirow{2}{*}{\multicolumn{2}{|c|}{$\begin{array}{l}\text { NTIS Price Codes } \\
\text { Microfiche A01 }\end{array}$}} \\
\hline & \\
\hline \multicolumn{2}{|c|}{ Printed Copy } \\
\hline & Price \\
\hline Pages & Codes \\
\hline $001-025$ & $\mathrm{~A} 02$ \\
\hline $026-050$ & $\mathrm{~A} 03$ \\
\hline $051-075$ & A04 \\
\hline $076-100$ & A05 \\
\hline $101-125$ & A06 \\
\hline $126-150$ & A07 \\
\hline $151-175$ & $\mathrm{~A} 08$ \\
\hline $176-200$ & A09 \\
\hline $201-225$ & A010 \\
\hline $226-250$ & A011 \\
\hline $251-275$ & A012 \\
\hline $276-300$ & A013 \\
\hline
\end{tabular}




\begin{abstract}
A METHOD FOR DETERMINING "ALLOWABLE RESIDUAL CONTAMINATION LEVELS" OF RADIONUCLIDE MIXTURES IN SOIL
\end{abstract}

B. A. Napier

May 1982

Prepared for the U.S. Department of Energy under Contract DE-AC06-76RLO 1830

Pacific Northwest Laboratory Richland, Washington 99352 


\section{ACKNOWLEDGMENTS}

The Allowable Residual Contamination Level (ARCL) method as described in this document has evolved from numerous discussions with I. C. Nelson, C. M. Unruh, and E. C. Watson of the Pacific Northwest Laboratory; D. E. Wood of Rockwel 1 Hanford Operations; Project Manager, C. E. Jenkins; and other personnel involved wi th the Hanford Defense Waste Environmental Impact Statement. 


\section{EXECUTIVE SUMMARY}

This report presents a method for answering the question "How clean is clean enough?" in relation to cleanup of sites with radioactive contamination. The method described is based on compliance with a radiation dose rate limit through a site-specific analysis of the potential for radiation exposure to individuals. The site-specific analysis is directed by the physical, environmental, and radiological characteristics of the contaminated area.

The method described in this report is being used as a basis for calculating impacts and costs associated with various high-level and transuranic waste disposal alternatives which will be examined in the proposed Hanford Defense Waste Environmental Impact Statement.

Example applications of the proposed method are given. Results of the examples show that the method yields allowable residual contamination levels of radionuclides in soil comparable to those promulgated by the Nuclear Regulatory Commission and by other researchers, for disposal scenarios similar to those postulated by these other groups. Consequently, one use of this method could be to consolidate the various recommendations for decontamination and decommissioning cleanup levels under a single radiation dose rate 1 imit.

A portion of the method described includes a technique for allowing credit for natural and engineered barriers to waste migration, nuclide transport, and human exposure. The examples provided indicate that application of proper barriers can help existing contaminated sites meet radiation dose rate 1 imits for times long into the future. This method can be used to evaluate proposals for "in-situ disposal" (in-place disposal) of presently contaminated areas with the aid of additional barriers.

Use of a dose-based, rather than an arbitrary, limit for radionuclide concentration allows site-specific disposal criteria and implementation methods, based on local pathways, to be developed. Analys is of the examples provided shows that transuranic (TRU) nuclides may be left in amounts 
in excess of $10 \mathrm{nCi} / \mathrm{gram}$, for some selected locations. Moreover, disposal techniques that result in greater confinement of the wastes than those normally used can permit even higher allowable residual contamination levels. 


\section{ABSTRACT}

An important consideration in the disposal of radioactive wastes, and consequently in the preparation of plans for remedial actions at contaminated sites, is the amount of radioactive contamination that may be allowed to remain at any particular waste site. The allowable residual contamination level (ARCL) is dependent on the radiation dose 1 imit imposed, the physical and environmental characteristics of the waste site, and the time at which exposure to the wastes is assumed to occur. The steps in generating an ARCL are generally as follows:

1. develop plausible, credible site-specific exposure scenario;

2. calculate maximum annual radiation doses to an individual for each radionuclide based on the existing physical characteristics of the waste site and the site-specific exposure scenario;

3. calculate the $A R C L$ for the dose 1 imit desired, including all radionuclides present, uncorrected for site cleanup or barrier considerations; and

4. apply any corrections for proposed cleanup activity or addition of barriers to waste migration or uptake to obtain the ARCL applicable to the proposed action.

Use of this method allows appropriate application of resources to achieve uniform compliance with a single regulatory standard, i.e., a radiation dose rate 1 imit.

Application and modification of the ARCL method requires appropriate models of the environmental transport and fate of radionuclides. Example calculations are given for several specific waste forms and waste site types in order to demonstrate the technique and generate comparisons with other approaches. 


\section{CONTENTS}

ACKNOWLEDGMENTS

EXECUT IVE SUMMARY

iv

ABSTRACT

vi

LIST OF FIGURES

$\mathrm{ix}$

LIST OF TABLES .

\subsection{INTRODUCTION}

1.1 EXISTING SOIL CONTAMINATION STANDARDS $\quad$ • $\quad . \quad$. $\quad$ • 2

1.2 NEED FOR A RESIDUAL CONTAMINATION STANDARD . . . $\quad 3$

2.0 THE ALLOWABLE RESIDUAL CONTAMINATION (ARCL) METHOD. . . 5

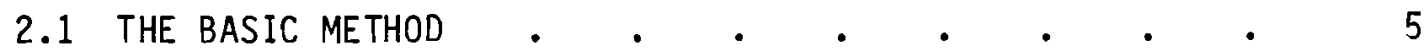

2.1 .1 Summary of the Method . . . . . . . 6

2.1.2 Extension of Results to Disposal . . . . . 8

2.2 ALLOWABLE RES IDUAL CONTAMINATION LEVELS (ARCL) . . 9

2.2.1 Maximum Annual Dose . . . . . . . 9

2.2.2 Radiation Exposure Pathways . . . . . . 11

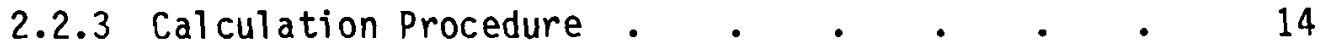

2.2 .4 Modification Factors . $\quad . \quad$. $\quad . \quad$. 15

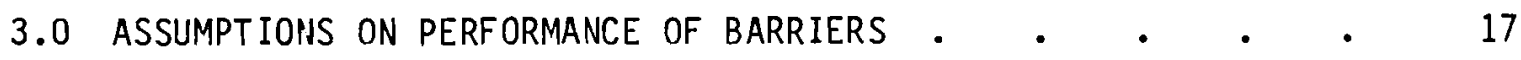

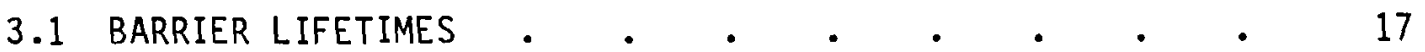

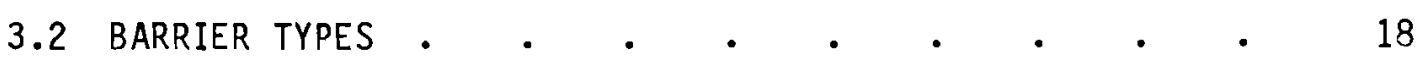

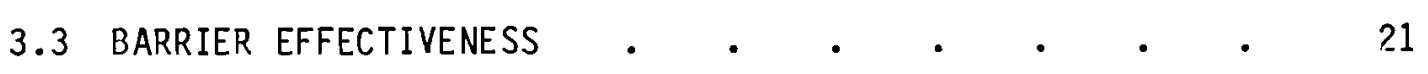

3.3.1 Natural Barriers . . . . . . . . . . 22

3.3.2 Engineered Barriers . . . . . . 25

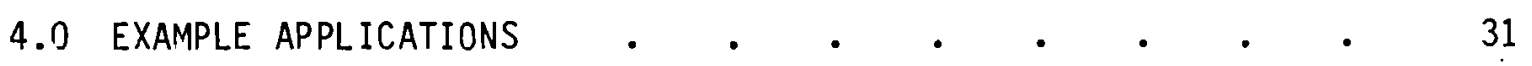

4.1 CONTAMINATED SURFACE SOIL. • • • • • • • $\quad 33$

4.1.1 Surface Contamination Exposure Scenarios . . 33 
CONTENTS (Continued)

4.1.2 Example Allowable Surface Contamination . . 34

4.2 SUBSURFACE SOIL CONTAMINATION •

4.2.1 Subsurface Contamination Exposure Scenario . . 37

4.2.2 Example Allowable Subsurface Contamination . . 40

4.2.3 Simplification for Similar Hanford Sites . . 45

$\begin{array}{lll}5.0 & \text { COMPARISON OF ARCL RESULTS WITH OTHER RECOMMENDATIONS • } & 47\end{array}$

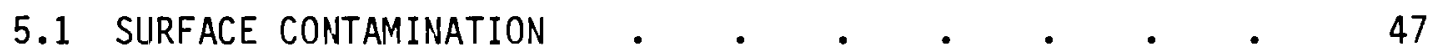

5.2 SUBSURFACE CONTAMINATION .

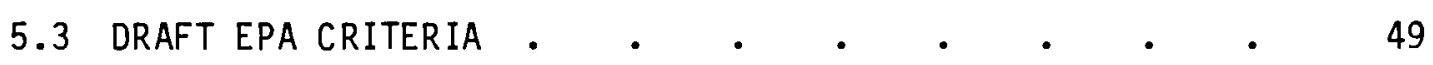

5.4 POTENTIAL USES OF THE ARCL METHOD • • . • . 52

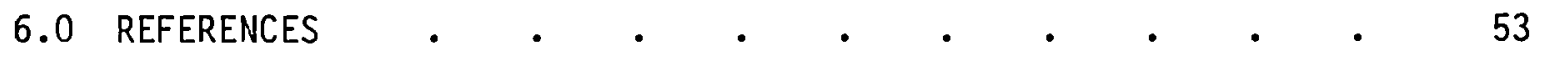




\section{FIGURES}

2.1 ARCL Method Logic Diagram . . . . . . . 7

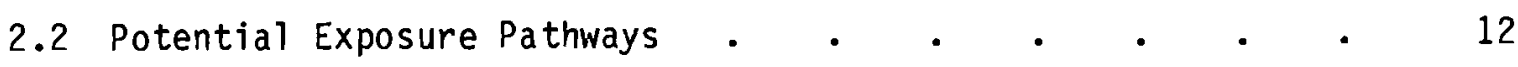

3.1 Estimated Wind Erosion Rates by Soil Type . . . . . 23

3.2 Crop Root Penetration Depths in the Absence of Barriers. $\quad 24$

4.1 Important Hanford-Specific Exposure Pathways . . . . . 32 


\section{$\underline{\text { TABLES }}$}

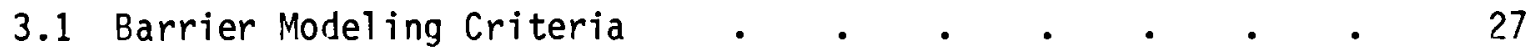

4.1 Unmodified Maximum Annual Doses for a Near-Term and a Far-Term Exposure Scenario for the Seepage Disposal Systems. .

4.2 ARCL Derived for a Design Objective of $500 \mathrm{mrem} /$ year at any Future Time for Seepage Pond Disposal Systems . $\quad$ - 36

4.3 Present Contamination Levels of Site 218-W-4B (Trenches) • 40

4.4 Unmodified Maximum Annual Dose by Parent Nuclide for Example Site 218-W-4B, Normalized to 1980

Soil Concentrations $. \quad . \quad . \quad . \quad . \quad . \quad . \quad . \quad . \quad 41$

4.5 Al lowable Residual Contamination Levels (ARCL) for Site 218-W-4B for $500 \mathrm{mrem} /$ year Design Objective . . . 43

4.6 Results of Equation 3 for Site $218-W-4 B$ (Trenches Only) . . . . . . . . . . 44

4.6 Hanford Radionuclide Inventories of In-Tank Defense
Waste as a Function of Time $. \quad . \quad . \quad . \quad . \quad . \quad . \quad 46$

5.1 Contamination Levels that Result in Individual Annual Doses of $500 \mathrm{mrem} /$ year to Bone Derived from Various References .

5.2 Comparison of 10 CFR Part 61 Disposal Concentration Values with Site-Specific Calculations for Hanford 


\subsection{INTRODUCTION}

An important consideration in developing plans for remedial actions for areas with radioactive contamination, or for designing radioactive waste disposal sites, is the amount of radioactive contamination that can be allowed to remain in the area at the termination of activities. This contamination level may dictate the cost and complexity of a cleanup action or define the activity limits of material that can be disposed of in a particular waste disposal site. This report is a description of a method for determining al lowable residual contamination levels for radionuclides in soil as a function of specific waste site characteristics. The basis of the method is a single radiation dose rate limit. Compliance with the limit is assured through site-specific exposure pathway analyses. Use of this method can aid in the development of site-specific engineering procedures for decontamination and/or decommissioning of contaminated areas by providing the basis for determining levels to which the various sites must be cleaned.

The method described in this report was developed by the Environmental Analysis Section, Environmental Sciences Department, of Pacific Northwest Laboratory. It is being used in the preparation of an Environmental Impact Statement (EIS) related to the final disposal of defense-related nuclear wastes presently stored at the Department of Energy's Hanford Site. The method will be the basis of estimates of soil volumes, and extent of remedial actions required, for the calculation of impacts and costs to be included in the proposed Hanford Defense Waste EIS.

The remainder of this section provides a brief review of current and proposed regulations regarding residual contamination, and the need for a comprehensive decommissioning standard. The basic ARCL method, and some enhancements, are described in Sections 2 and 3 . Examples of the application of the method are given in Section 4. Results obtained with the method are compared wi th current standards in Section 5. 


\subsection{EXISTING SOIL CONTAMINATION STANDARDS}

The problems of human exposure to very low levels of residual contamination have been of interest to many researchers. Nomalized radiation dose conversion factors have been prepared at Oak Ridge National Laboratory for 50-year dose commitments from one year of exposure to radionuclides pertinent to decontaminating facilities (Hill 1979) and at Pacific Northwest Laboratory for 70-year accumulated doses from similar exposures (Napier et a1. 1980a). A major study at Los Alamos National Laboratory of radiation doses from exposure to residual contamination has continued for several years (Healy and Wenzel 1976); detailed pathway analyses have been performed at Los Alamos for plutonium isotopes (Healy 1977), radium and its daughters (Healy and Rodgers 1978), and uranium decay chain members in soil (Healy, Rodgers and Wienke, 1979). Others have studied the hazards of uncontrolled uranium mill tailings piles (Schiager 1978; Clements et al. 1978) or of low-level waste burial grounds (Murphy and Holter 1980). Residual contamination levels have been investigated for the DOE nuclear sites at Idaho Falls (Chapin 1980) and Hanford (Boothe 1979). Both of these latter two analyses were based on site-specific information, but both assume perpetual control of the site by governmental entities, with only restricted future uses permitted.

Criteria for operation and/or decommissioning of nuclear facilities have been adopted by the Nuclear Regulatory Commission (Federal Register 1981 a, 10 CFR 140 1980), the Environmental Protection Agency (40 CFR 190, 40 CFR 192, EPA 1977), and the former Atomic Energy Commission (AEC 1974). These criteria are the present basis for evaluating acceptable soil contamination levels for unrestricted release of property. The EPA has proposed two specific soil contamination standards: one for transuranics, the other for 226Ra. The standard for 226Ra has been adopted as a temporary standard. The State of Colorado has adopted a standard for permissible plutonium levels in the soil of uncontrolled areas (Hayden 1980). Soil standards have also been set for Enewetak Atoll based on a dose calculation model designed specifically for that atoll (Barnes 1978). 
In addition to the preceding existing regulations, new regulations have been proposed by the EPA (40 CFR 191) and the IRR (10 CFR 191). The EPA criteria, currently in draft form, define a set of "release limits" for radionuclides from ecologic repositories. The ARC proposal, recently released for public comment (Federal Register 1981b), has similarities to the method proposed here, but is restricted to 1 icensing requirements for a generic 10 level waste burial ground. Comparisons of the ARCL method results with both of these proposed standards are given in Sections 5.2 and 5.3 .

\subsection{MEED FOR A RESIDUAL CONTAMINATION STANDARD}

It is difficult to directly compare the limits given in most of the cited standards and studies since each is intended for a specific situation and a variety of units are used. The number of radionuclides considered ranges from one to a11. Some limits specify radionuclide concentration levels in soil, some specify an acceptable dose or dose rate. However, methods have been proposed by Healy (1974, 1979), Pacific Northwest Laboratory (Oak, et a1. 1980), and by Oak Ridge National Laboratory (Eckerman and Young 1980) that can be used to calculate allowable residual contamination levels for any mixture of radionuclides. These methods all involve a radiation exposure pathway analysis to determine the contamination limits which rely on an acceptable annual dose. An improved method of this type is described in this report.

The method for determining an allowable residual contamination level (ARCL) described in this report is similar in many respects to that used by the NRC to develop draft criteria for shallow land burial grounds (NRC 1981a). The essential difference is in the final application. The ARCL method of this report is intended for site-specific use at the several existing diverse contaminated areas. The NRC desired "a generic nonsite-specific classification system which can be uniformly applied by waste generators and disposal facility operators" to avoid "an extreme range in requirements and controls based on the particular site-related requirements for disposal" (NRC 1981a, page 7-3). The NRC approach may be appropriate for regulating new 
disposal operations, but is inadequate for evaluating existing areas of contamination. A standard based on a single dose limit, assured by a sitespecific analysis, is needed. 


\subsection{THE ALLOWABLE RESIDUAL CONTAMINATION LEVEL (ARCL) METHOD}

The objective of the analysis of ARCL of radionuclides in soil is the determination of whether any particular waste site requires further attention prior to unrestricted release. The results of analysis also indicate the general magnitude of any remedial actions. However, some simple extensions of the method can be used to refine proposed actions for each site. If the preferred action is recovery of a waste site, the method can indicate the degree of contamination retrieval necessary. If the preferred action is "in-situ disposal" (i.e., leaving the waste in place, possibly with additional barriers to waste migration), the method can be used to analyze the effectiveness of proposed engineered barriers. If continued storage and/or surveillance is preferred, the method can provide an indication of the time period for which controls will be required.

This section outlines the basic approach, indicates how the initial results can be modified to give estimates of actions required, and provides a few basic definitions. Refinements to the method are described in Section 3.

\subsection{THE BASIC METHOD}

The calculation of ARCLs of radionuclides in soil is dependent on the physical characteristics of each individual waste site (size, depth, radionuclide inventory), on the radiation dose limit determined to be "acceptable," and on the scenarios judged to be both possible and to result in upper bounds of human exposure to the waste. The physical characteristics can be determined from a complete site description, and the scenarios must be established for each site depending on that descriotion, including description of the waste. Dose limits for waste sites have not yet been set by regulatory agencies. The draft generic environmental impact statement on decommissioning nuclear facilities (NRC 1981b) contains a recommendation that the allowable residual radioactivity level for facility release be based on the dose anticipated to be received by individuals who use that facility. As set forth in the Energy Reorganization Act of 1974, the EPA has responsibility for establishing radiation dose standards 
for the protection of public health and safety. Thus, the EPA has responsibility for establishing criteria for residual radioactivity limits. FPA has not yet instituted these criteria and is not scheduled to do so until 1984 (NRC 1981b). An example $1 \mathrm{imit}$ of $500 \mathrm{mrem} / \mathrm{yr}$ is used in this report as a design objective.

\subsubsection{Summary of the Method}

A simplified logic diagram of the ARCL method is shown in Figure 2.1. As illustrated, the necessary prerequisite to any analysis is a characterization of the individual waste site, including location, size, depth, radionuclide inventory, and descriptions of existing barriers to waste migration. These details allow preparation of a realistic site-specific radiation exposure scenario. The heart of the ARCL method is an analysis of the maximum annual radiation dose possible to an exposed individual. If the dose potential to the individual is less than the design objective dose limit, then no further actions are required for that waste site. If it is predicted that the potential dose may exceed the design objective, the need for remedial action is indicated.

The general method for calculating the allowable residual contamination level of radionuclides in soil consists of four steps:

1. From information presented in the site description, develop a plausible scenario for transfer of radionuclides to an onsite resident individual.

2. From the radionuclide inventory given in the site description, calculate the maximum annual radiation dose by radionuclide to the onsite individual for the site scenario (specific characteristics associated with each site), unmodified by depth or barrier concerns.

3. Calculate the ARCL for all nuclides in the mixture, applying a depth of burial correction. This calculation is performed for times that may maximize the exposure. 


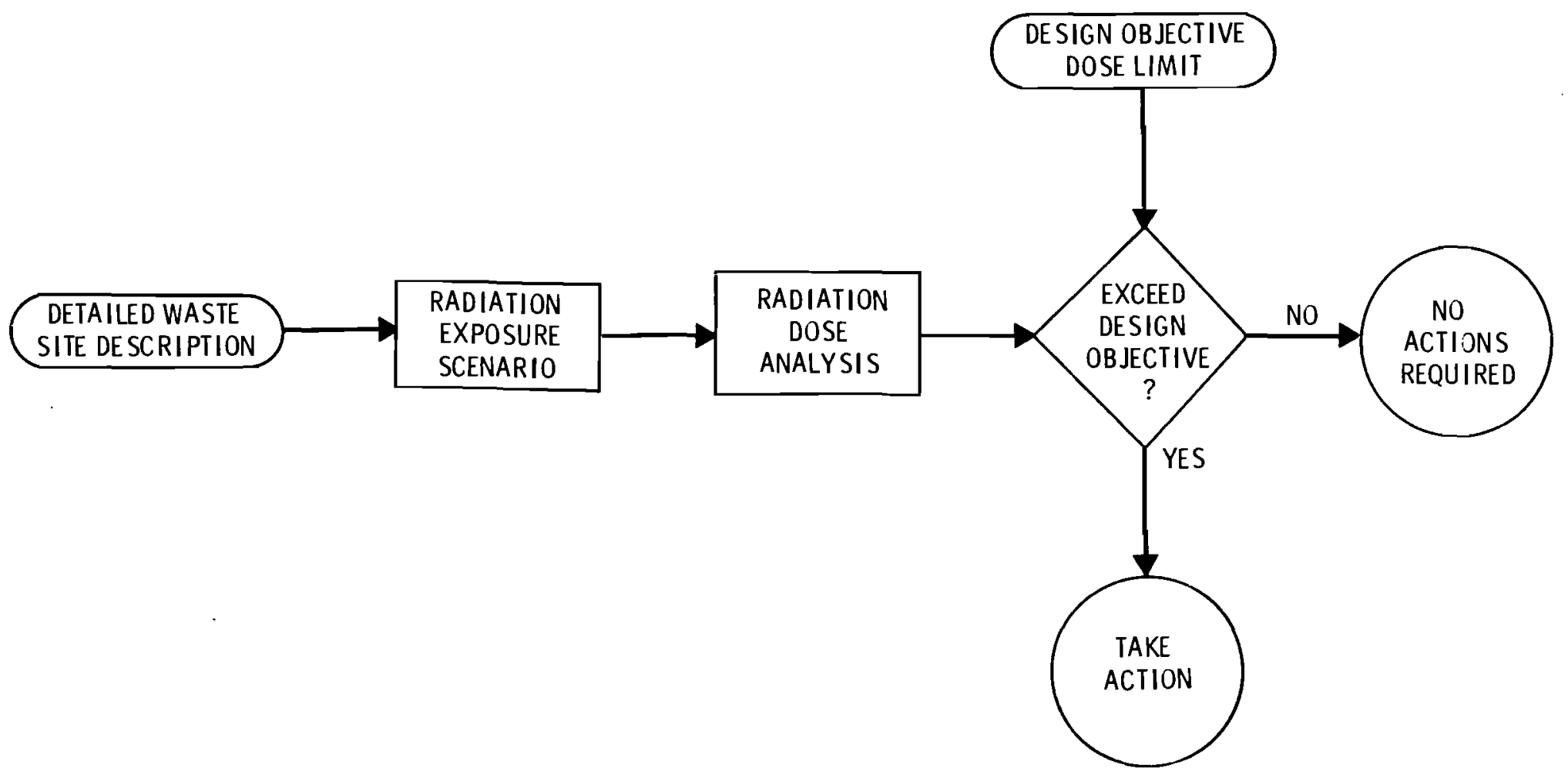

FIGURE 2.1 ARCL Method Logic Diagram 
4. Test whether application of additional engineered barriers will improve the waste site characteristics, using a correction similar to the depth of burial correction.

\subsubsection{Extension of Results to Disposal}

The primary objective of the ARCL is a screening determination of whether or not an individual waste site requires remedial actions. A secondary objective is the determination of what remedial actions could be effective. The ARCL method does not choose the most appropriate disposal al ternative, nor does it automatically provide the best means of hazard mitigation. Analysis of remedial actions is simply an extended analysis of a waste site with modified physical characteristics.

A nearly infinite range of possible waste management strategies is available for each waste site. These could include the alternatives of continued surveillance with routine maintenance and site control, total removal of the wastes, or in-situ disposal with construction of impenetrable barriers. The most likely strategy is some mixture of these.

The ARCL method is not directly applicable to the alternative of continuing surveillance and maintenance. Control of the waste site is assumed to prevent people from casual or intentional exposure. However, the potential exposures can be analyzed at various times in the future as an indicator of how long control must be maintained over the site.

For the alternative of waste exhumation and removal, the ARCL method gives a direct indication of the allowable residual contamination. From this, the quantities and volumes of soil that must be retrieved can be estimated.

Analysis of the alternative of in-situ disposal requires several applications of the ARCL modeling. For many types of waste sites, the potential radiation doses are controlled by short-lived fission products. It is relatively easy to develop engineered barriers that will reduce the dose potential for a few hundred years--the time period of concern for most fission products. However, if there is also a sufficient quantity of longlived or transuranic (TRU) wastes in a site, barriers lasting much longer 
may be required. It is, therefore, necessary to analyze the site with short-term barriers, and if indicated, with more complex long-term barriers.

Many options are possible for the final physical form of stabilized, decommissioned waste sites. Depth of burial, erosion potential, waste migration barriers, and packaging type can all vary from site to site. The dose estimation models are generally unable to explicitly characterize all the potential variables, therefore, simplifying assumptions must be marle. The following sections introduce the mechanics of the method and present various parameters necessary for modeling.

\subsection{ALLOWABLE RESIDUAL CONTAMINATION LEVELS (ARCL)}

The design objective is a limit on the maximum annual radiation dose to an individual. The annual dose is a function of the quantity and spectrum of contaminant radionuclides and the exposure pathways to man. The design objective limit is converted to a site specific, measurable quantity, the ARCL in pCi/gram of soil. Each of these concepts is described in this section.

\subsubsection{Maximum Annual Dose}

The method used in this report for determining ARCL for unrestricted public use of decommissioned nuclear facilities is a comparison of a calculated maximum annual dose received by a maximally-exposed individual with annual dose limits. When internal exposure from inhalation and/or ingestion is the dominant dose contributor, the maximum annual dose may not occur in the first year. Thus, a first-year dose will not predict the most restrictive contamination level. Alternative methods might be to calculate the 50-year dose commitment from one year of exposure or to calculate the 1 ifetime integrated dose from continuous exposure; however, no recognized standards limiting these types of doses exist. Thus, the maximum annual dose is appropriate for use in determining ARCL.

The PNL computer program MAXI (Napier et a1. 1979, Murphy and Holter 1980) can be used to calculate maximum annual doses from a large number of 
exposure pathways. The MAXI program incorporates the inhalation exposure models of DACRIN (Houston et a1. 1974, Strenge et a1. 1975), the terrestrial and aquatic pathways of FOOD and ARRRG (Napier et al. 1980b), and has special modifications for resuspension and well-water scenarios.

The general expression for calculating the annual dose to an organ of reference during any year after the start of continuous exposure can be expressed as (Murphy and Holter 1980, Kennedy et a1. 1979):

$$
A_{t}=R_{t}^{\star}+\sum_{j=1}^{t-1}\left(R_{j,(t-j+1)}-R_{j,(t-j)}\right) ; t>1
$$

where

$$
\begin{aligned}
& \text { At - the annual dose during the year } t \text { from all exposure pathways } \\
& \text { to the organ of reference, mrem; } \\
& R_{t}^{*} \text { - the radiation dose equivalent in year } t \text { to the organ of } \\
& \text { reference from all internal and external exposure pathways } \\
& \text { from intake and exposure in the year } t \text {, mrem; and } \\
& R_{j, k} \text { - the radiation dose equivalent commitment to year } k \text { to the } \\
& \text { organ of reference from internal exposure pathways from intake } \\
& \text { in previous year } j \text {. }
\end{aligned}
$$

The summation term represents the dose equivalent delivered to the organ of reference in year $t$ from radionuclides deposited in the organ from intake in all previous years since the start of continuous exposure.

The summation term in Equation 1 is valid only for integer values of $t$ greater than 1. For values of $t$ equal to or less than 1, the subscripts define a nonreal case, and the summation term is set equal to zero.

The annual dose, $A_{t}$, to the organ of reference is calculated for each value of $t$ from 1 to 50 , and the maximum annual dose is determined by inspection. The radionuclide inventories are adjusted for radionuclide decay and daughter-product buildup during the calculation. 


\subsubsection{Radiation Exposure Pathways}

The key to the ARCL method, as shown in Figure 2.1, is an analysis of the maximum annual radiation dose to an individual. This analysis is dependent on the exposure scenario chosen, which depends on the physical characteristics of the waste site. Choice of the exposure scenario is what makes the $A R C L$ method flexible to many types of waste site, inventory, and location.

The potential routes by which people may be exposed to radionuclides or radiation are called "exposure pathways." Exposure pathways that could be considered for buried waste are illustrated in Figure 2.2. The ARCL for waste sites is based on the sum of exposures through all the selected pathways. The pathways illustrated in Figure 2.2 include direct contact with the waste, such as could occur if the buried materials were disturbed. The pathways of leaching and groundwater transport are also shown, with the possible exposure modes resulting in doses to man. Al so shown are the pathways resulting from biotic intrusion, such as would occur for an agriculture scenario.

Onsite Resident Individual

Preliminary investigations were performed to examine the location of the individual most likely to be affected by waste sites. Individuals were postulated to live downwind and downstream at distances of $10 \mathrm{~km}(5.2 \mathrm{mi})$ and $1 \mathrm{~km}(3280 \mathrm{ft})$, and onsite. For all exposure scenarios and at all times, radiation dose rates to the individuals living out of the immediate vicinity of the waste were found to be orders of magnitude smaller than those received by the onsite individual. Thus, the onsite exposure scenarios were determined to be the most critical.

Many waste sites are not currently available for casual intrusion by individuals, since they are in restricted locations. This complicates the choice of exposure scenario. Use of the more restrictive of a near-term scenario and a far-term scenario overcomes this problem. The near-term scenario is used to calculate maximum doses to an individual in the public for the present land use, and the far-term is used to calculate potential 


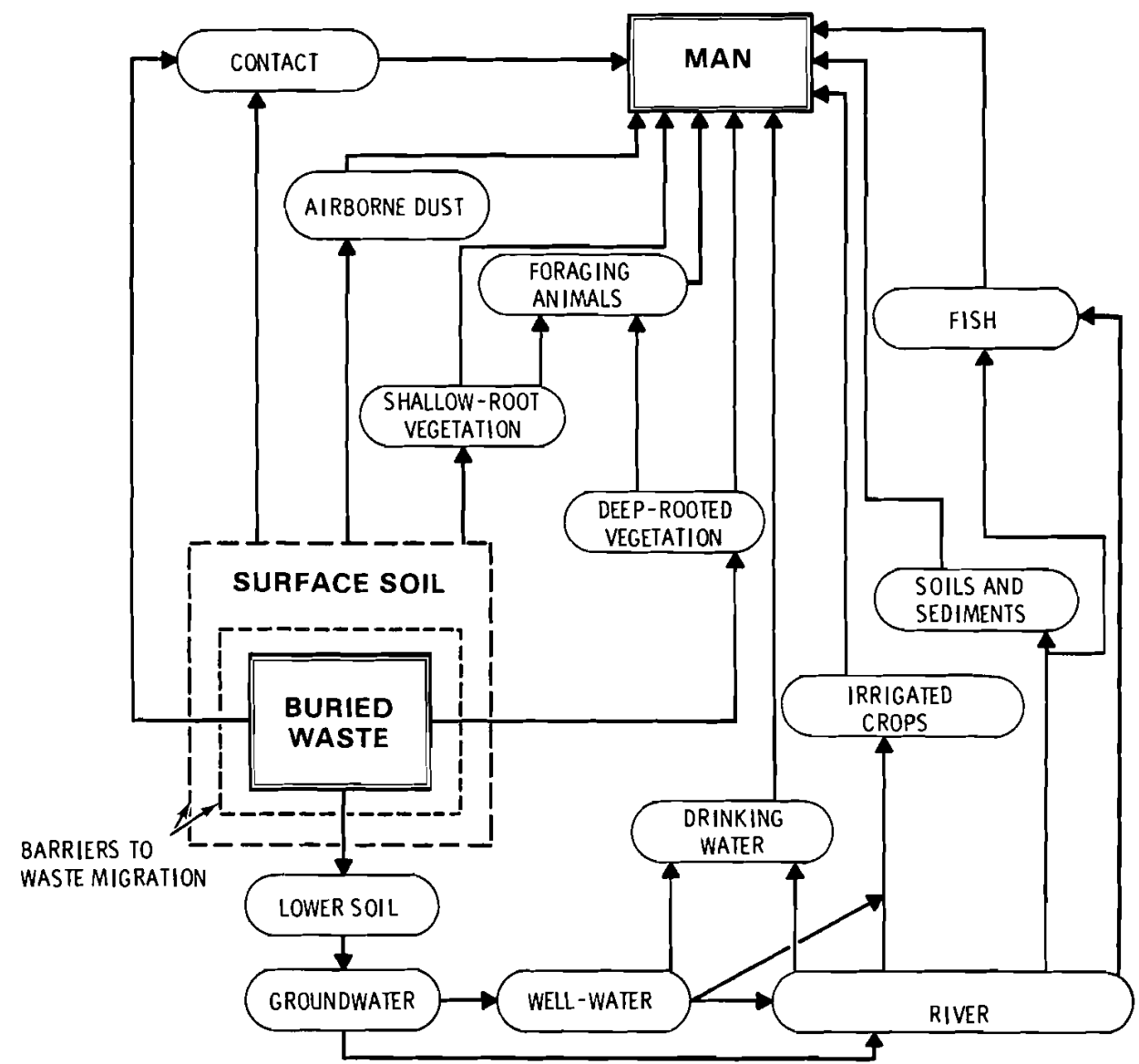

FIGURE 2.2 Potential Exposure Pathways 
doses for possible changes in site accessibility. Generally, for the farterm scenario, it may be assumed that people will eventually move onto the waste site. This is not intended to imply that future populations are unintelligent or technologically inferior, but only that records of the waste sites are forgotten or ignored. Doses to these people will depend on the size, depth, radionuclide inventory, and availability of wastes buried near their residences.

The potential for exposure to radiation enhanced by natural events such as floods or glaciers is not included in the onsite individual calculation.

\section{Intruders}

An onsite resident individual is assumed to have no more contact with the waste than is occasioned by his having a garden. Anyone who disturbs the waste more than a gardener would be considered an "Intruder," and a dose calculation separate from the design objectives should be made for such a person. This "Intruder" category could include excavation, drilling, or archaeology. For some cases, the potential for high probability intruders could limit tolerable options; however, this is not considered in the first analysis with the design objectives.

\section{Time Considerations}

To be most useful, the allowable residual soil concentration of a radionuclide mixture should be calculated for the time at which the remedial action is anticipated to occur. This allows rapid comparison of the actual contamination with the calculated ARCL. Thus, an ARCL calculated for an exposure scenario postulated to occur several hundred years following the remedial action should be normalized to the existing waste site concentration by accounting for radioactive decay. For events that may happen at any time in the future, the most restrictive level of present concentration should be chosen to maintain future dose potential below the dose limit. In practice, this means that several "time windows," out of the future continuum, should be selected. For the purpose of example in this report, ARCL for times $100,400,1000$, and 10,000 years from time zero 
are tabulated. These times are chosen to represent the soonest time people could possibly be expected to move onsite (100 years), the time most fission products require to decay to essentially innocuous levels (400 years), and as representatives of the 1 ong term (1000 and 10,000 years). Other time windows may be chosen if the postulated scenario requires them.

\subsubsection{Calculation Procedure}

Once the exposure pathways and associated parameters are defined, the maximum annual doses to the controlling organ are calculated by radionuclide for uniformly contaminated soil. If more than one pathway contributes and if mitigation procedures affect each pathway differently, such doses are calculated for each pathway. The doses are calculated for the years of interest (at which people move onsite or barriers are assumed to fail) and, for simplicity, normalized to present conditions accounting for radioactive decay. Dose rates calculated in this step are "Unmodified Maximum Annual Doses" (UMAD). The term "unmodified" refers to the fact that as of yet no depth or barrier corrections have been applied. The doses are normalized to units corresponding to mrem/year at time of interest per $\mathrm{pCi} / \mathrm{gram}$ at present, or equivalent. For this report, these doses have been calculated using the PNL computer package MAXI, but other equivalent pathway analysis codes could be used.

The ARCL for nuclide $i, P_{j}$, can now be related to the design objective dose rate by ratio of the UMAD with the design objective, accounting for modifiers, such as depth of burial and barriers, as:

$$
P_{i}\left(p C_{i} / g\right)=\frac{D O(m r e m / y r)}{\operatorname{UMAD}_{j}(m r e m / y r \text { per } p C i / g)} I_{j} M_{j}
$$

where

Dn - the radiation dose design objective, i.e., the chosen dose limit to an individual;

UMAD $i$ - the unmodified maximum annual dose for nuclide $i$ for the site-specific exposure scenario; and 
$M_{j}$ - modification factors to correct for depth of burial, areal extent, presence of barriers, and other modifiers. These factors are further descrihed in Sections 2.2.4 and 3.0.

Solution of this equation yields the ARCL amount for each radionuclide in isolation. For mixtures of radionuclides, the further consideration that

$$
\sum_{\mathbf{i}} \frac{p_{\mathbf{i}}}{P_{\boldsymbol{i}}} \leq 1
$$

must hold, where $\rho_{i}$ is the actual residual concentration of radionuclide $i$, and $P_{i}$ is the ARCL of that nuclide in isolation. When this condition is satisfied, the waste site meets the design objective dose criterion, and requires no further remedial actions. Should this ratio be greater than unity, then the need for remedial action (either waste recovery or installation of barriers) is indicated. The relative magnitude of the result is an indicator of the amount of remedial action required.

\subsubsection{Modification Factors}

The ARCL for any radionuclide, or mixture of nuclides, at a site may be increased to allow credit for site-specific conditions or barriers to waste migration. Allowances for these credits are designed as multiplicative enhancement factors, $M_{j}$. These modifiers are fully described in Section 3.0 .

The modifying factors are of two general forms. The first is exponential, as

$$
M_{j}=e^{a d}
$$

where "a" is a constant and " $d$ " is a variable such as dedth of overburden. The more general form is

$$
M_{j}=100\left(100-E_{k}\right)^{-1}
$$


where $E_{k}$ is the percent effectiveness of barrier type $k$ in reducing radiation dose. Many modifiers may be used simultaneously, as for modeling a buried waste trench with multiple barriers. Suggested values of the factor $E_{k}$ for various barriers are given in Section 3.0 . 


\subsection{ASSUMPTIONS ON PERFORMANCE OF BARRIERS}

Anything that impedes the transport of radionuclides or radiation from the waste to an exposed individual can be considered to be a barrier. Modeling the effect of barriers over long time periods is complicated by the need to consider changes in the barrier and even in the physical surroundings of the barrier with time. Therefore, the potential for degradation of barriers and erosion of overburden means that, even accounting for radioactive decay, waste sites could become more hazardous in the future. This section contains assumptions that may be used if sitespecific information on the performance of barriers is lacking.

\subsection{BARRIER LIFETIMES}

To quote M. L. Wheeler and W. J. Smith, "Perpetual is Not Forever" (Wheeler and Smith 1979). No barrier to waste migration (movement of radionuclides away from its original engineered location) can be expected to be 100 percent effective for more than a period of a few decades. Unexpected or unpreventable occurrences will continuously degrade any barrier applied. While there still exist many massive, ancient structures, no studies and few projections suggest that near-surface engineered constructions, other than immense piles of earth or rock, would still be in a condition to be considered fully effective as a barrier for more than a few hundred years. For the purpose of modeling, it is assumed that the effective 1 ife of a barrier is about 300 years following cessation of maintenance. Maintenance is assumed to keep the barriers in good condition as long as there is institutional control, and the barriers perform their function for 300 years after that. After that time, the efficacy of most man-made barriers is assumed to drop to either zero or to some fraction of initial efficiency. Since an active institutional control is often considered to last about 100 years, the addition of a barrier increases the total time assumed for radioactive decay to 400 years.

Many radionuclides potentially present in waste sites have half-lives of many thousands of years. Even if a waste site can be shown to be acceptable immediately following loss of active institutional control or 
degradation of 400-year barriers, the potential still exists for the site to pose hazards to individuals far into the future. Therefore, the additional analysis times of 1000 and 10,000 years are considered. The 10,000year period is chosen for several reasons. It is sufficiently long for ground-water transport mechanisms to be identified. The migration of many nuclides is so low that a shorter period would not provide sufficient time for potentially hazardous trends to develop. On the other hand, 10,000 years is relatively short on a geologic time scale. Major geologic changes, such as development of a faulting system or a volcanic region, take much longer than 10,000 years, so the likelihood and characteristics of geologic events which might disrupt the waste are reasonably predictable over this period. Finally, 10,000 years is consistent with assumptions made by EPA for analyzing nuclear waste repositories (Draft 40 CFR 191).

It is assumed that any disposal method that is capable of adequate protection for 10,000 years will continue to protect the pub1ic and the environment for periods well beyond that time.

\subsection{BARRIER TYPES}

Many types of barrier might be used to prevent waste migration or waste site degradation. The processes which are important to mitigate are generally erosion, biotic intrusion, and water infiltration. There is little that can be done to prevent intentional human intrusion. A definition of the various single barrier types that have been proposed are given here.

Soil: Any natural overburden located on top of the waste site. As a rule, existing waste site coverings are considered to be soil. Soil acts as a general shield to radiation, water penetration, and root penetration. Soil is subject to wind and water erosion.

Biobarriers: Any device or circumstance that acts to reduce the fraction of plant roots or burrowing animals reaching the waste and hence reduces the migration of waste from the site. 
Vegetative Cover: The establishment of a shallow-rooted ground cover to control wind and water erosion. In dry climates, vegetation is assumed to require some level of maintenance and watering to survive; therefore, after 400 years ground cover is assumed to have reverted back to native plants. In moist climates, it is assumed to be superceded by deeply rooted plants in about the same time frame.

Clay Layer: Various bentonite-type clays have been proposed as stabilizing caps for waste burial grounds in order to prevent gas escape and water infiltration. It is assumed that any clay cover is capped with a further barrier against erosion. Most clays are subject to expansion and contraction depending on moisture content. This cycling results in cracking of the clay. In dry climates, this alternating cycle is assumed to el iminate the efficiency of a several-centimeter-thick clay layer after 400 years.

Membranes: A thin, uniform sheet composed of plastic, rubber, or other composite sheeting or a thinly applied layer of asphalt on polymeric material. Membranes are generally thought of in terms of water infiltration. They are usually thin, and fragile enough that their use is limited to short time frames.

Waste Tanks: Some of the wastes at DOE nuclear sites are contained in concrete/metal vessels. These tanks, while containing many perforations, probably have sufficient structural integrity to provide some waste insulation from roots and percolating water for several hundred years. Beyond 400 years, however, there is insufficient information to quantify an allowance for the tanks.

Asphalt: A surface or subsurface layer of asphalt several centimeters thick. This category does not include sprayed-on or thin-film asphalt emulsions. These are classed as "membranes."

Gravel: Thick layers (over $30 \mathrm{~cm}$ [12 in.]) of small stones (diameters up to about $10 \mathrm{~cm}[4 \mathrm{in.}$ ) used to prevent erosion and intrusion by plant roots, animals, or humans. These can be either surface or subsurface, but subsurface layers should be topped with a material to prevent soil from 
penetrating between the rocks. Subsurface layers are al so only of secondary importance for erosion control, providing a lower limit to erosion, but not holding the cover soil.

Rock: Layers of very large stones (diameters greater than $30 \mathrm{~cm}$ and up to $1 \mathrm{~m}$ [12 to $39 \mathrm{in.1)}$ used to prevent erosion or intrusion. These rocks should be of a stable form over geologic time (i.e., granite--not sandstone) (Winkler 1975, Lienhart and Stransky 1981). Also referred to as "riprap." It is assumed that a $1 \mathrm{~m}$ (39 in.) thick 1 ayer of rock reduces plant cover by 90 percent. Additional thickness of the rock 1 ayer reduces vegetation growth proportionately.

Large Rocks: Very large riprap, intended to deter human intrusion as well as minimize plant growth and erosion. Stones in excess of 1 meter diameter.

Hard Cover: A lid of concrete or steel placed on or under the soil surface, over the waste. Depending on the material used, its thickness can vary from about 2 to $20 \mathrm{~cm}(<1$ to $4 \mathrm{in.}$ ). It is assumed to degrade over time to the point that, after the 400 years its effectiveness is reduced to that of a layer of gravel.

Chemical Agents: Any number of various chemicals toxic to plant roots. Organic toxins, such as triflurilan, need to be encapsulated in some sort of time-release form. Inorganics might be preferable; however, the question is raised as to the morality of intentionally poisoning the local environment with long-lived inorganic toxins. While these toxins might be useful in controlling invading plants, the question of further environmental pollution by their use has not been fully addressed.

Surface Contouring: The grading, scraping, or other movement of surface soils to alter site contours. Such site-topography adjustment can be used to control water runoff, smooth surfaces, or minimize wind erosion.

Glass Waste Form: Should the option be taken to remove high-level wastes from tanks, process it, and return it to the tanks as glass balls, or fragments, it will have a leach rate 0.1 percent of that of unprocessed 
material (DOE 1980). This same effectiveness is assumed for the recently developed PNL process of electric in-situ vitrification for buried wastes.

Package Integrity: Buried waste may take many forms, some of which may reduce the possibility of waste migration. Most boxes and drums will loose their integrity during long-term storage in the ground. However, some nuclides, such as those in activated metal or encased in concrete or glass will be less available for plant root uptake than if they were homogeneously mixed in soil. Inherent chemical toxicity of the waste may al so reduce plant root availability.

\subsection{BARRIER EFFECTIVENESS}

There is little information available which can be used to quantify the degree to which the previously defined barriers can fulfill their design functions, especially over long periods of time. Also, essential to the design and implementation of effective and durable harriers are the interactions among component parts of multi-part barriers. For example, the choice of surface stabilization method can affect the amount of moisture percolating to ground water. The dynamics of the water would affect the potential for contaminant leaching, mass wasting (i.e., the soil column could become saturated with water and as a result be unable to support a large rock cover), and the composition of the eventual biotic community (e.g., plant and animal species, rooting depth, and presence of burrowing animals). It is apparent that one variable cannot always be maximized without impacting others. Therefore, it is important that the design of long-term barriers be derived from a systems approach, considering the interactions of the various biotic and abiotic components.

While barriers cannot be designed without full consideration of all component interactions, preliminary assessments must approximate the effectiveness of individual barriers, and then combinations of barriers. Assumptions are provided here to allow modeling of various combinations of barrier types where accurate site-specific information is lacking. These are not intended to preclude the development of better values in the future. 


\subsubsection{Natural Barriers}

Modeling the radiation dose rate to hypothetical onsite individuals requires many assumptions about future conditions, personal habits, and mitigating factors. It can be assumed that climatic and topographic conditions will remain essentially the same as they are now, and that humans will behave as they do now. For some important parameters, there is insufficient data to project far into the future. Assumptions needed are described in this section, as well as appropriate methods of applying them to dose results.

\section{Erosion}

Some radionuclide release mechanisms are a direct result of the reshaping of the earth's surface by natural forces such as water erosion, wind erosion, and subsidence.

Water and wind erosion are functions of climate, topography, soil properties, ground cover, and human activities at or near the waste site. Wind erosion is the wearing away of the surface soils by moving air. Wind erosion is a complex function of climate, topography, soil properties, ground cover, and human activities. A curve of wind erosion rate as a function of soil type is given in Figure 3.1. For most moderately rocky soils, a value of $0.1 \mathrm{~mm} / \mathrm{yr}$ is suggested. For waste sites with fine or sandy soil, a value of $1.0 \mathrm{~mm} / \mathrm{yr}$ should be used.

Subsidence refers to the sinking or collapse of the ground surface. It can al ter the surface features in ways that may enhance wind or water erosion. Buried waste forms; bulky, non-compacted wastes; insufficiently compacted fill; and waste package deterioration can all result in subsidence. While these may not be a severe problem for liquid waste disposal sites such as cribs or reverse wells, it is estimated that, with present burial practices, as much as 30 percent of burial-ground trench volume may be void space (EPA 1978). It is assumed that site maintenance performed before site release corrects subsidence problems, and that they tend to become less severe wi th time as waste sites settle. 


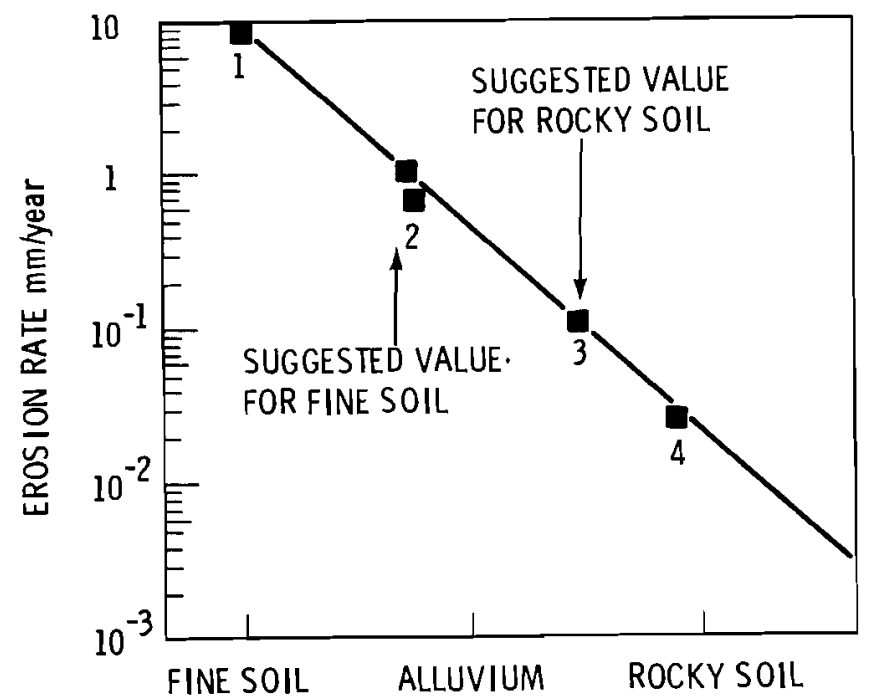

\section{REFERENCES}

1. 10. $\mathrm{mm} /$ year (WATS ON 1980)

2. $0.6 \mathrm{~mm} /$ year FOR WESTERN US (MURPHY 1980)

3. $0.1 \mathrm{~mm} /$ year FOR WES TERN US (WHEELER 1979)

4. $0.025 \mathrm{~mm} /$ year FOR LONG-TERM EROS ION AT HANFORD (TUBBS 1979)

FIGURE 3.1 Estimated Wind Erosion Rates by Soi1 Type

\section{Root Penetration}

For a waste site covered with a layer of clean soil or overburden, the inhalation exposure pathway is eliminated and the direct irradiation pathway is reduced to insignificance. Therefore, the dominant pathway for exposure becomes consumption of plants that have roots penetrating the waste. The fraction of plant roots in the waste is a function of the type of plant and the depth that the waste is buried. Estimates of the fractions of active plant roots below a given depth are given in Figure 3.2.

Certain desert plants have taproots reported to grow to depths approaching $10 \mathrm{~m}(33 \mathrm{ft})$. Most garden crops usually do not grow much below about $3 \mathrm{~m}(9.8 \mathrm{ft})$, but some crops such as al fal fa do often exceed $7 \mathrm{~m}$ (23 ft). Crop uptake of radionuclides is assumed to be directly proportional 


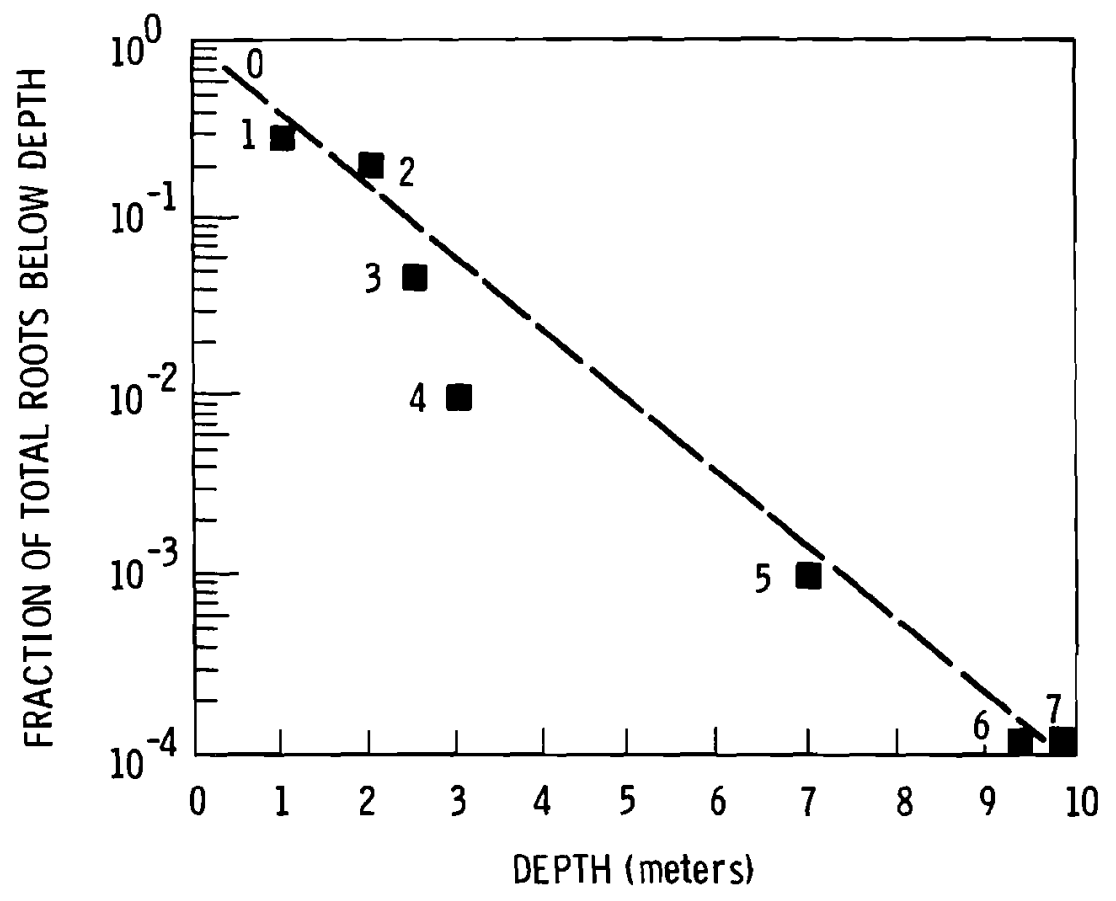

REFERENCES

0. $100 \%$ OF PLANT ROOTS ASSUMED TO BE AT OR BELOW SOIL SURFACE

1. $70 \%$ OF ALFALFA ROOTS ARE IN THE TOP 1 meter (WSU 1970)

2. 80\% OF TOMATO ROOTS ARE IN THE TOP 2 meters (SUNSET)

3. $95 \%$ OF GRAPE ROOTS ARE IN THE TOP 2.5 meters (SUNSET)

4. EFFECTIVE DEPTH OF MOST GARDEN CROPS (SUNSET) LOWER DEPTH OF SOME GRASS ROOTS (DEPT. AG . 1951)

5. EFFECTIVE DEPTH OF ALFALFA (WSU 1970, DEPT. AG. 1951)

6. LOWER REPORTED DEPTHS FOR TUMBLEWEED AND GREY RABBIT BRUSH

7. ARBITRARY $10 \mathrm{~m}$ LOWER CUTOFF

FIGURE 3.2 Crop Root Penetration Depths in the Absence of Barriers 
to the fraction of active roots in the waste. Therefore, the concentration of radionuclides in plants grown over a site is scaled logarithmically with depth as shown in the figure. The references given with this figure are intended to direct the interested reader to pertinent information, and the exact values plotted may not be given in the references.

An arbitrarily assumed cutoff of $10 \mathrm{~m}(33 \mathrm{ft})$ is used as lower limit below which crop roots do not penetrate.

It is not the intent of this definition to imply that a surface cover of $10 \mathrm{~m}(33 \mathrm{ft})$ of soil is necessarily a sufficient barrier. The concept of ALARA still applies. Safety analysis calculations for "intruders" or natural release mechanisms should al so be conducted which may indicate an impetus for further cleanup efforts.

Certain types of barriers, such as a layer of large rocks, greatly reduce the total amount of vegetation growing over an area. A barrier that reduces the total quantity of vegetation is modeled the same way as a barrier that reduces the penetration of roots into the waste.

\subsubsection{Engineered Barriers}

In general parlance, the term "barrier" refers to the engineered protections described in Section 3.2. Different barrier types have different functions, but one that is applied for one reason may also impact another variable. Estimated percent effectiveness of performing the desired function ( $E_{k}$ in Equation 5 ) of various barrier types are listed in Table 3.1 for the release mechanisms of erosion, vegetation, penetration, and water infiltration. These values are presented mostly as "orderof-magnitude" estimates; the use of these barriers could result in order of magnitude reductions in an individual's annual dose rate, or allow a corresponding increase in the ARCL while still meeting the dose design objective. Most barrier types are assumed to deteriorate with time, through weathering, subsidence, and plant and animal penetration. The values in Table 3.1 for 400-year-old barriers reflect the lowered degree of effectiveness assumed. 
The references given in Table 3.1 are intended to aid the reader in obtaining more detailed information about each barrier type. Few references give more than qualitative information regarding barrier efficiency and lifetime; therefore, the values in Table 3.1 are engineering estimates. They are given to aid preliminary analyses, and are not meant to suggest that the development of more accurate values in the future would be unwarranted. 
TABLE 3.1 Barrier Modeling Criteria

Percent Effectiveness

Barrier Type

First 300 Years Beyond 300 Years

References

A. Vegetation Availability Reduction (Biobarriers)

Vegetative cover

$\mathrm{Cl}$ ay 1 ayer

Membranes

Waste tanks

Asphalt

Gravel

Additional soil

Rocks

Hard cover

Chemical agents

(intentionally

applied)

90

10

60 per meter

90 per meter

100

100

0

0

0

99

90

0

0

10

60 per meter

90 per meter

0

0

10

0

10


TABLE 3.1 (Continued)

Percent Effectiveness

Barrier Type

First 300 Years Beyond 300 Years

References

B. Wind Erosion Reduction (continued)

\begin{tabular}{|c|c|c|c|}
\hline Rocks & 100 & 100 & Murphy 1 \\
\hline Hard cover & 100 & 10 & $\begin{array}{l}\text { Murphy } 1 \\
\text { Macbeth }\end{array}$ \\
\hline Chemical agents & 0 & 0 & Murphy \\
\hline \multicolumn{4}{|l|}{ Waste form: } \\
\hline $\begin{array}{l}\text { Salt cake, exposed } \\
\text { Concrete, exposed } \\
\text { Glass, exposed }\end{array}$ & $\begin{array}{r}0 \\
90 \\
99\end{array}$ & $\begin{array}{r}0 \\
10 \\
90\end{array}$ & $\begin{array}{ll}\text { NAS } & 1978 \\
\text { NAS } & 1978 \\
\text { NAS } & 1978\end{array}$ \\
\hline
\end{tabular}

C. Reduction of Water Infiltration and Percolation

Surface contouring

Vegetative cover

Clay layer

Membranes

Waste tanks

Asphalt
90

90

10

90

90

90

0

0
Murphy 1980

Duguid

Murphy 1980

EPA 1978

Hughes 1975

Macbeth 1978

Hawkins 1967

Duguid

EPA 1978

Murphy 1980

Macbeth 1979

Duguid

EPA 1978

Cline 1980

Macbeth 1979

Cline 1979

EPA 1.978

Cline 1980

Macbeth 1979

Cline 1979

EPA 1978 
TABLE 3.1 (Continued)

Percent Effectiveness

\begin{tabular}{|c|c|c|c|}
\hline Barrier Type & First 300 Years & Beyond 300 Years & References \\
\hline Gravel & 0 & 0 & Cline 1980 \\
\hline Rocks & 0 & 0 & Cline 1980 \\
\hline Hard cover & 50 & 0 & $\begin{array}{l}\text { Murphy } 1980 \\
\text { Macbeth } 1979 \\
\text { EPA } 1978\end{array}$ \\
\hline Chemical agents & 0 & 0 & Macbeth 1979 \\
\hline \multicolumn{4}{|c|}{ D. Availability Reduction for "Package Integrity" } \\
\hline Cardboard box & 0 & 0 & Horton 1978 \\
\hline Wooden box & 0 & 0 & Horton 1978 \\
\hline $\begin{array}{l}\text { Fiberglass coated } \\
\text { box }\end{array}$ & 0 & 0 & Arbitrary \\
\hline Metal box & 0 & 0 & Arbitrary \\
\hline Drum & 0 & 0 & Arbitrary \\
\hline Activated metal & 90 & 10 & Murphy 1980 \\
\hline $\begin{array}{l}\text { Surface contamina- } \\
\text { tion }\end{array}$ & 0 & 0 & Hol comb 1979 \\
\hline Undefinable junk & 0 & 0 & Horton 1979 \\
\hline \multicolumn{4}{|l|}{ Waste Immobilization: } \\
\hline Salt cake toxicity & 90 & 90 & NAS 1978 \\
\hline $\begin{array}{l}\text { Concrete } \\
\text { (grout, etc) }\end{array}$ & 90 & 10 & $\begin{array}{l}\text { NAS } 1978 \\
\text { Mishima } 1980\end{array}$ \\
\hline Glass & 99.9 & 99.9 & $\begin{array}{l}\text { NAS } 1978 \\
\text { DOE } 1980\end{array}$ \\
\hline
\end{tabular}




\subsection{EXAMPLE APPLICATIONS}

The dependence of allowable residual contamination levels on the specific characteristics of the waste site is perhaps best illustrated by example calculations. The difference possible between contaminated surface soil and buried wastes is shown in the following example applications.

Two examples are provided, one for surface soil contamination and one for subsurface soil (buried) contamination. Each example contains a brief waste site description, site specific exposure scenarios for onsite individuals, a table of unmodified maximum annual doses (UMAD) for each scenario at various times in the future, and the resulting ARCL of each radionuclide.

For simplicity, both examples are given for the same basic site location, the 200 Area Plateau of the Department of Energy's Hanford Site. A generalization for Hanford of the second (buried waste) example is also provided.

For the majority of Hanford waste sites, in the Hanford 200 Areas, the ground-water pathways have been found to be only marginal contributors to dose. The distance from the waste to the ground water, in excess of 60 meters, coupled with the sorptive properties of Hanford soils and the low annual rainfa11, results in 1 ittle radionuclide migration (NAS 1978, Issacson 1978). Studies have further shown that, even if the radionuclides are leached to ground water, offsite population doses are very small (Wallace 1980). Thus, transport of nuclides through the vadose zone to ground water can be neglected for most Hanford sites.

Elimination of the ground-water pathways reduces the pathways of concern to the resident individual to direct radiation, inhalation of resuspended material, and ingestion of contaminated crops and animal products. This simplification is illustrated in Figure 4.1. The relative importance of each of these pathways is a function of time of exposure. 


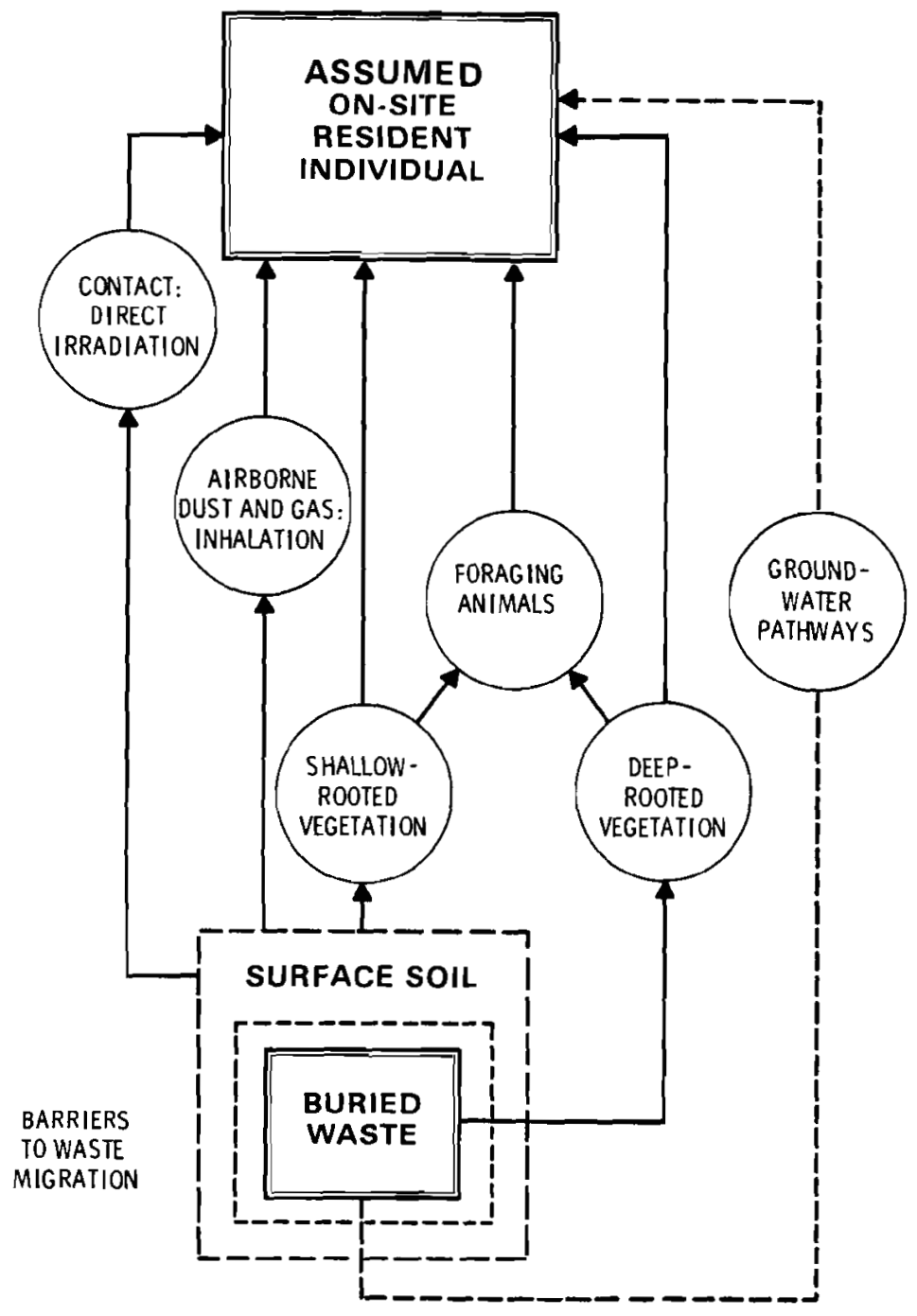

FIGURE 4.1 Important Hanford-Specific Exposure Pathways 


\subsection{CONTAMINATED SURFACE SOIL}

Soil can be contaminated through accidental spills, intentional dumping (as of mine or mill tailings), or other mechanisins. A number of lowlying areas on the Hanford Site have been used for many years as seepage ponds for disposal of low-level contaminated process water. Continued use of these ponds has resulted in the accumulation of inventories of transuranic and fission product isotopes in the pond bottomm sediments (ERDA 1975, Last and Duncan 1980). Most ponds are completely artificial, maintained by a constant influx of recharge water. When disposal of water in these ponds ceases, the dramatically lowered water level may expose the fine-grained, contaminated sediments. As an example application of the ARCL method, allowable residual levels of soil contamination are developed for the possibility of removal of the contaminated sediments for disposal el sewhere.

\subsubsection{Surface Contamination Exposure Scenarios}

When the water influx to the various ponds ceases, the ponds, having no direct contact with the water table, will dry out. The exposure pathways of concern will be external exposure, inhalation of resuspended particles, and possible future agricultural pathways. The pond site will remain within a restricted zone for the near future, thus two potential exposure scenarios must be investigated to determine the most restrictive cleanup levels, assuming the desired disposition mode is to remove the contaminated soil. (The case of buried contamination is given in Section 4.2.) The first scenario involves near-term exposure of workers near the site to direct irradiation and inhalation of resuspended materials (in this it follows the work of Boothe 1979). The second scenario involves possible future inhabitants with the same exposure modes and, in addition, a contribution from garden crops that might be grown on site after an appropriate period of radioactive decay.

The exposure parameters for the first scenario are dependent entirely on how long an individual is assumed to be exposed to the waste site. Maximum would be a person stationed adjacent to the pond area for 2000 hours 
per year. This individual would be exposed to the radiation field of the pond and to resuspended materials.

A number of resuspension models are available. These include simple resuspension rates, resuspension factors and mass loading factors, as well as more complicated functions of vegetation, soil erodibility, or topography. A number of investigators suggest the use of a mass loading of $10^{-4} \mathrm{~g} / \mathrm{m}^{3}$ in the absence of specific data for western sites for predictive purposes (Anspaugh 1974, Healy 1979). This value was also used in a recent study of nuclear waste burial grounds (Murphy and Holter 1980).

Use of a mass loading factor of $10^{-4} \mathrm{~g} / \mathrm{m}^{3}$ corresponds to an average annual wind erosion rate of less than $2 \mathrm{~mm} /$ year, or a rate of nearly 32 MT/year per hectare. This erosion rate is fairly low by the standards of Murphy and Holter, 1980; but it corresponds closely with the assumptions of Figure 3.1 for fine-grained soils.

For the second scenario, the time of exposure is increased to 8760 hours per year, and consumption of home-grown garden vegetables is included. The ingestion pathways used for this analysis are those of the standard Hanford maximally-exposed individual (Napier 1981). This individual is assumed to raise a large fraction of his own fruits and vegetables for personal consumption. These parameters reflect the agricultural practices prevalent in the south central Washington Columbia Basin (Bustad and Terry 1957, Essig and Corley 1969). Exposures by this second scenario are not assumed to start for at least 100 years.

\subsubsection{Example Allowable Surface Contamination}

The unmodified maximum annual doses to an individual resulting from the two exposure scenarios described in Section 4.1 .1 are given in Table 4.1 for selected radionuclides. They are presented for one time window for the first scenario and two time windows for the second scenario. Inspection of the UMADs in this table shows that the second scenario has the greatest potential for exposing individuals to radiation for all radionuclides except cesium-137. The dose rates in scenario 2 are less at 1000 
TABLE 4.1 Unmodified Maximum Annual Doses for a Near-Term and a Far-Term Exposure Scenario for Seepage Pond Disposal Systems (mrem/year per pCi/gram)

\begin{tabular}{|c|c|c|c|}
\hline \multirow[b]{2}{*}{ Radionuclide } & \multirow{2}{*}{$\begin{array}{l}\text { Scenario } 1 \\
\text { (Present) } \\
\end{array}$} & \multicolumn{2}{|c|}{ Scenario 2} \\
\hline & & (100 Years) & (1000 Years) \\
\hline SR-90 & $6.2 E-3(a)$ & $9.7 E+0$ & 0 \\
\hline Cs -137 & $6.6 \mathrm{E}-1$ & $2.8 \mathrm{E}-1$ & 0 \\
\hline$U-238$ & $6.2 \mathrm{E}-2$ & $5.2 \mathrm{E}-1$ & $3.5 E+0(b)$ \\
\hline Pu-239 & $2.1 \mathrm{E}-1$ & $9.6 \mathrm{E}-1$ & $9.4 \mathrm{E}-1$ \\
\hline$A m-241$ & $2.1 \mathrm{E}-1$ & $8.5 \mathrm{E}-1$ & $2.0 \mathrm{E}-1$ \\
\hline
\end{tabular}

(a) The E-format notation used in this report should be read as $6.2 \mathrm{E}-3=6.2 \times 10^{-3}$.

(b) Increases to $1.0+2$ at 10,000 years.

years than at 100 years for all nuclides except uranium-238, for which long-lived daughter products are accumulating.

The ARCL of each of these radionuclides for a $500 \mathrm{mrem} / \mathrm{year}$ dose limit is given in Table 4.2. The ARCL are derived from the most restrictive of the UMADs of Table 4.3, except for that for uranium-238. Because the daughters of the uranium chain do not reach secular equilibrium with the parent for many thousand years, the result for U-238 is based on 10,000 years of decay time.

Because most of the ARCL values in Table 4.3 are based on the second exposure scenario, it is apparent that cleanup efforts are required more to protect individuals in the long term than to reduce occupational exposure to workers in the short term. This is a result of the 1 imited exposure pathways that can be postulated for workers in a controlled situation, as opposed to the more varied pathways possible following unrestricted release.

\subsection{SUBSURFACE SOIL CONTAMINATION}

Waste storage and disposal operations can result in contamination of subsurface soil. For well-designed sites, there is no resuspension of 
TABLE 4.2 ARCL Derived for a Design Objective of $500 \mathrm{mrein} /$ year at any Future Time for Seepage Pond Disposal Systems

\begin{tabular}{cc} 
Radionuclide & ARCL $(\mathrm{pCi} / \mathrm{g})(\mathrm{a})$ \\
\hline Sr-90 & 50 \\
$\mathrm{Cs}-137$ & 800 \\
$\mathrm{U}-238$ & $5(\mathrm{~b})$ \\
Pu-239 & 500 \\
Am-241 & 600
\end{tabular}

(a) All values have been rounded to one significant figure.

(b) Based on 10,000 year decay time.

contaminated material, so the inhalation pathway need not be evaluated. Surface cover or overburden also reduces the direct irradiation dose rate.

The example waste disposal site used to demonstrate calculation of ARCL for buried waste is the Hanford TRU storage/waste disposal site 218-W-4B, located near the western edge of the Hanford 200 West Area. It consists of 12 trenches of unsegregated waste, each about $177 \mathrm{~m} \times 9 \mathrm{~m} \times 4 \mathrm{~m}$ $(580 \times 29 \times 13 \mathrm{ft})$, one segregated TRU trench about $177 \mathrm{~m} \times 13 \times 2 \mathrm{~m}(580 \times$ $43 \times 6 \mathrm{ft}$ ), and 12 caissons, which are concrete and metal bins buried below ground. For this example, only the 281-W-4B trenches are considered. A complete description of the site is given in the reference letter by Merrick (1981).

Burial ground $218-W-4 B$ is a fairly representative waste disposal area on the Hanford Site. The radiation exposure scenario developed in Section 4.2.1 for the site is thus general enough to be applied to most waste disposal areas at Hanford. The values of UMAD calculated for this site have been used, with appropriate modifications for surface area, depth of overburden, and existing barriers, to determine ARCL for most contaminated areas at Hanford. These results have been used to estimate the levels of remedial action required, resulting costs, and environmental impacts for the upcoming Hanford Defense Waste EIS (HDW-EIS). Because no annual dose limits for release of waste sites now exist, the ARCL analysis 
for the HDW-EIS uses a parametric approach, applying three design objective dose rate limits. The three dose rates chosen for analysis are:

- $25 \mathrm{mrem} / \mathrm{yr}$, selected as a lower value based on present Environmental Protection Agency (EPA) standards for nuclear fuel-cycle operations (40 CFR 190), developing EPA standards for HLW operations (draft 40 CFR 191), and proposed Nuclear Regulatory Commission (NRC) standards for 1ow-level waste management operations (Federal Register 1981b);

- $100 \mathrm{mrem} / \mathrm{yr}$, selected as a mid-range value equal to the natural radiation background in the Hanford area; and

- $500 \mathrm{mrem} / \mathrm{yr}$, selected as an upper value based on proposed NRC lowlevel waste disposal standards, present NRC standards (10 CFR 20.105), International Commission on Radiation Protection (ICRP) recommendations, and present Department of Energy (DOE) guidance (AEC 1973 ).

\subsubsection{Subsurface Contamination Exposure Scenario}

The EPA defined "Accessible Environment" (40 CFR 191) to be:

"The Earth's atmosphere, 1and surface, surface waters, and those underground sources of drinking water that are more than one mile in any (horizontal) direction from the original location of the radioactive wastes in a disposal system."

For the waste sites at Hanford, radioactive wastes are effectively isolated at present from the atmosphere and local surface waters. The Hanford hydrology/geology effectively isolates them from the ground water. A critical point becomes the definition of "land surface." All soils within the upper $10 \mathrm{~m}(33 \mathrm{ft})$ of the earth's crust can be assumed to be within a potentially biologically active zone. Of direct concern is transport of nuclides within this zone to the actual surface by biological or physical means. While localized "hot spots" can result from animal action, the overall radionuclide migration caused by animal action has not yet been fully evaluated. This pathway may be revised at a later date, depending on future research (McKenzie, et a1. 1982). 
The 218-N-4B burial ground site is currently in a restricted area and is expecter to remain so for the foreseeable future. Dose rates to workers in the vicinity of the buried wastes are negligible. However, over a very long period, the site may again become accessible to the general public. Persons may move onsite in the future and engage in activities such as construction and small farming. It is necessary to compare the surface area of the waste site with the garden size required for an individual to raise his entire annual consumption of garden vegetables. This step does not have a well-defined algorithm, but as a general rule for Hanford conditions an area of about one hectare (about 2.5 acres) is assumed to be required to grow an individual's complete supply of vegetables. For sites smaller than one hectare $(2.5$ acres $)$, the consumption parameters are reduced accordingly. This reduction of consumption parameters has the same effect as averaging the contamination over a larger garden surface area. For larger sites, the individual consumption rates are not increased, but more people are assumed to be involved. Standard Hanford exposure parameters are used (Napier 1981). For small sites, only vegetable crops are assumed. For sites with a large surface area, pathways including foraging animals can be included.

The example waste site has an overall surface area of about 4 ha (10 acres). Therefore, it is of sufficient size to support one to four persons consuming $230 \mathrm{~kg} /$ year of garden-grown vegetables, but small enough so that a potential contribution from grazing animals is small.

Other assumptions used are:

1. From the site description (Merrick 1981), the waste is assumed to be homogeneously distributed in the soil. The information given in the site description implies that most of the waste is in a fom that makes package integrity considerations unimportant.

2. The waste is below an overburden of $1.3 \mathrm{~m}(4 \mathrm{ft})$ of dirt. Therefore, $30 \%$ of plant roots could have penetrated the waste at times 100 and 400 years from the present. In 10,000 years, the rocky soil may be assumed to have eroded about one meter, so the root penetration would increase to $70 \%$. 
3. The isotopic composition of the uranium is assumed to be:

$\begin{array}{lcll}\text { Isotope } & \text { Activity, \%* } & & \text { Wgt \%* } \\ & 35 & & 0.0046 \\ \text { U-233 } & 37 & & 0.0074 \\ \text { U-234 } & 1.1 & 0.55 \\ \text { U-235 } & 27 & 99\end{array}$

4. The site description indicates that there are about $52 \mathrm{~kg}$ (139 1b) of TRUs in this site. The plutonium isotopic composition is assumed to be:

\begin{tabular}{|c|c|c|}
\hline I sotope & Activity, $\%^{*}$ & Wgt $\% \star$ \\
\hline $\mathrm{Pu}-238$ & 0.5 & 0.007 \\
\hline Pu-239 & 23 & 93 \\
\hline $\mathrm{Pu}-240$ & 5.8 & 6.4 \\
\hline $\mathrm{Pu}-241$ & 70 & 0.17 \\
\hline $\mathrm{Pu}-242$ & 0.002 & 0.14 \\
\hline
\end{tabular}

The values in assumptions 3 and 4 are derived from estimations of the present inventories of radionuclides in Hanford waste sites made using the ORIGEN computer program. Similar isotopic breakdowns for existing Hanford wastes, and wastes projected to be generated, can be derived from information given in the documents RHO-LD-141 (Rockwel1 1980) or RHO-HS-ST-1 (Rockwe11 1982).

5. The TRUs are primarily located in a retrievable storage area, al though the entire site is somewhat contaminated with TRU waste.

6. The assumed current inventory and resulting contamination levels are those given in Table 4.3.

*A1 1 values have been rounded to two significant figures. Therefore, percentages may not add to 100 . 
TABLE 4.3 Present Contamination Levels of Site 218-W-4B (Trenches)

\begin{tabular}{|c|c|c|}
\hline Radionuclides & $\begin{array}{l}\text { Total Curies } \\
\text { In Trenches (a) }\end{array}$ & $\begin{array}{c}\text { Specific Activity } \\
(\mathrm{p} C \mathrm{i} / \mathrm{g}) \\
\end{array}$ \\
\hline Co-60 & $1.4 E+3$ & $1.4 E+4$ \\
\hline $5 r-90$ & $2.8 E+2$ & $2.9 \mathrm{E}+3$ \\
\hline Cs-137 & $3.1 E+2$ & $3.1 E+3$ \\
\hline$T h-232$ & $6.1 \mathrm{E}-2$ & $6.2 \mathrm{E}-1$ \\
\hline$U-233$ & $7.4 \mathrm{E}+1$ & $7.5 E+2$ \\
\hline$U-234$ & $2.6 E+0$ & $2.6 E+1$ \\
\hline$U-235$ & $7.9 \mathrm{E}-2$ & $7.9 E-1$ \\
\hline$U-238$ & 1. $9 \mathrm{E}+0$ & $1.9 \mathrm{E}+1$ \\
\hline$P u-238$ & $6.8 \mathrm{E}+1$ & $6.8 \mathrm{E}+2$ \\
\hline $\mathrm{Pu}-239$ & $3.0 \mathrm{E}+3$ & $3.0 \mathrm{E}+4$ \\
\hline $\mathrm{Pu}-240$ & $7.6 E+2$ & $7.6 \mathrm{E}+3$ \\
\hline Pu-241 & $9.2 E+3$ & $9.3 E+4$ \\
\hline $\mathrm{Pu}-242$ & $2.7 \mathrm{E}-1$ & $2.8 E+0$ \\
\hline$A m-241$ & $2.1 E+0$ & $2.2 E+1$ \\
\hline Total & $1.5 E+4$ & $1.5 \mathrm{E}+5$ \\
\hline
\end{tabular}

(a) From Merrick (1981).

\subsubsection{Example Allowable Subsurface Contamination}

Given the conditions of assumption 1, the UMAD for sites of this type are given in Table 4.4. As described in Section 2.2.3, these are the largest annual doses that could be expected through the design objective scenario for 1980 concentrations of $1 \mu \mathrm{Ci} / \mathrm{gm}$. The doses include contributions from the ingrowth of decay chain daughter products with time. The LIMAD are given for time windows that correspond to possible loss of control of the site ( 100 years), potential barrier degradation as given in Table 3.1 (400 years), and the long term $(10,000$ years). 
TABLE 4.4 Unmodified Maximum Annual Dose by Parent Muclide for Example Si te 218-W-4B, Normal ized to 1980 Soil

Concentrations (mrem/yr per $\mu \mathrm{Ci} / \mathrm{g}$ )

\begin{tabular}{|c|c|c|c|c|}
\hline & Critical & Unmodified & Maximum Annual & Doses (UMAD) \\
\hline$\underline{\text { Radionuclide }}^{(a)}$ & Organ & Year 100 & Year 400 & Year 10,000 \\
\hline Co-60 & Total Body & $1.3 E-3$ & $0.0 \mathrm{EO}$ & $0.0 \mathrm{EO}$ \\
\hline $\mathrm{Ni}-59$ & Bone & $4 \cdot 3 E+4$ & $4.3 E+4$ & $3.9 E+4$ \\
\hline$S r-90$ & Bone & $6.0 E+6$ & $4.0 E+3$ & $0.0 \mathrm{EO}$ \\
\hline Tc-99 & GI-LLI & $3.5 E+5$ & $3.5 E+5$ & $3.4 E+5$ \\
\hline Cs-135 & Bone & $9.0 E+3$ & $9.0 E+3$ & $9.0 \mathrm{E}+3$ \\
\hline Cs -137 & Bone & $2.2 E+3$ & $2.2 E+0$ & $0.0 \mathrm{EO}$ \\
\hline$I-129$ & Thyroid & $3.3 E+7$ & $3.3 E+7$ & $3.3 E+7$ \\
\hline Sm-151 & GI-LLI & $1.4 E+3$ & $1.5 E+2$ & $0.0 \mathrm{EO}$ \\
\hline $\mathrm{Pb}-210$ & Bone & $5.8 E+6$ & $5.0 E+2$ & $0.0 \mathrm{E} 0$ \\
\hline $\mathrm{Ra}-226$ & Bone & $2.4 E+8$ & $2.1 E+8$ & $3.3 E+6$ \\
\hline Th-230 & Bone & $1.2 \mathrm{E}+7$ & $4.0 E+7$ & $2.3 E+8$ \\
\hline Th-232 & Bone & $2.0 E+6$ & $2.0 \mathrm{E}+6$ & $2.0 E+6$ \\
\hline$U-233$ & Bone & $5.0 E+5$ & $5.0 E+5$ & $4.8 E+5$ \\
\hline$U-234$ & Bone & $4.9 E+5$ & $5.6 E+5$ & $1.7 E+7$ \\
\hline$U-235$ & Bone & $4.7 E+5$ & $4.9 E+5$ & $1.1 E+6$ \\
\hline$U-238$ & Bone & $4.4 E+5$ & $4.4 E+5$ & $6.6 E+5$ \\
\hline $\mathrm{Np}-237$ & Bone & $7.9 E+5$ & $7.9 E+5$ & $8.1 E+5$ \\
\hline$P u-238$ & Bone & $6.5 E+3$ & $7.7 E+2$ & $6.1 E+3$ \\
\hline $\mathrm{Pu}-239$ & Bone & $2.3 E+4$ & $2.3 E+4$ & $1.8 E+4$ \\
\hline $\mathrm{Pu}-240$ & Bone & $2.3 E+4$ & $2.3 E+4$ & $8.1 E+3$ \\
\hline Pu-24.1 & Bone & $2.3 E+3$ & $1.5 E+3$ & $5.3 E+0$ \\
\hline $\mathrm{Pu}-242$ & Bone & $2.2 E+4$ & $2.2 E+4$ & $2.2 E+4$ \\
\hline$A m-241$ & Bone & $5.7 E+4$ & $4.1 E+4$ & $1.6 \mathrm{E}+2$ \\
\hline
\end{tabular}

(a) Radionuclides with half-lives less than 5 years, and that are not members of 1 ong- 1 ived decay chains, such as Ru-106 or Ce-144, do not contribute to the base scenario. 
There are many options for the stabilization of Hanford waste site 218-i-4B. They can be classed into two alternatives--retrieval of the waste or installation of engineered barriers. The most restrictive of the 100-year and 10,000-year ARCL can be used to determine the requirements for waste retrieval. These two can al so be used to determine if barriers are required for the in-situ disposal option. If barriers are required, the 400 year ARCL can be used to determine how effective the barriers must be at 400 years. These ARCL are derived from the UMAD of Table 4.4, and using the corrections of assumption 2, Section 4.2.1. These results are given in Table 4.5 for a design objective dose 1 imit of $500 \mathrm{mrem} /$ year. In essence, the need for action is determined by the most restrictive value for each radionuclide (either the 100 year or the 10,000 year column). The most restrictive value provides indication of how much waste must be retrieved for the alternative of waste exhumation. For the in-situ disposal alternative, there is potential need for either short-term (fission product) barriers or long-term barriers. This need can be determined by the use of the most restrictive of the 400 year and 10,000 year columns. In other words, a waste site to be disposed of in-situ that contains more than the most restrictive ARCL values (years 100 and 10,000 ), but not more than the most restrictive ARCL for years 400 and 10,000 , requires only a harrier adequate for about 300 years. If however, this site does exceed the allowable limits at either 400 or 10,000 years, then a 1ong-term barrier is required.

Table 4.6 gives the result of applying Equation 3 (Section 2.2.3) to Tables 4.4 and 4.5 for three radiation dose design objectives. Values greater than one indicate the need for action based on the radiation dose criterion. It is apparent from Table 4.6 that some action is required for this site. Values are given for 218-W-4B both with and wi thout removing the single high-TRU trench, because that trench, containing most of the TRU, is retrievable storage. Showing both sets of values in Table 4.6 provides an indication of whether cleaning up only the TRU is sufficient, or if an impetus remains for further action. 
TARLE 4.5 Allowable Residual Contamination Levels (ARCL) for Site 218-W-4B for $500 \mathrm{mrem} /$ year Design 0bjective

\begin{tabular}{|c|c|c|c|}
\hline \multirow[b]{2}{*}{ Radionucl ide } & \\
\hline & 100 yrs & 400 yrs & 10,000 yrs \\
\hline Co-60 & $1 E+12$ & $--(b)$ & -- \\
\hline $\mathrm{Ni}-59$ & $4 E+4$ & $4 E+4$ & $2 E+4(c)$ \\
\hline $5 r-90$ & $3 E+2$ & $4 E+5$ & -- \\
\hline Tc-99 & $5 E+3$ & $5 E+3$ & $2 E+3(c)$ \\
\hline Cs-135 & $2 E+5$ & $2 E+5$ & $8 E+4(c)$ \\
\hline Cs-137 & $8 E+5$ & $8 E+8$ & -- \\
\hline I -129 & $5 E+1$ & $5 E+1$ & $2 E+1(c)$ \\
\hline Sm-151 & $1 E+6$ & $1 E+7$ & -- \\
\hline $\mathrm{Pb}-210$ & $3 E+2$ & $3 E+6$ & - \\
\hline $\mathrm{Ra}-226$ & $7 E+0$ & $8 E+0$ & $2 E+2$ \\
\hline$T h-230$ & $1 E+2$ & $4 E+1$ & $3 E+0(c)$ \\
\hline$T h-232$ & $8 E+2$ & $8 E+2$ & $4 E+2(c)$ \\
\hline$U-233$ & $3 E+3$ & $3 E+3$ & $2 E+3(c)$ \\
\hline$U-234$ & $3 E+3$ & $3 E+3$ & $4 E+1(c)$ \\
\hline U. -235 & $4 E+3$ & $3 E+3$ & $6 E+2(c)$ \\
\hline$U-238$ & $4 E+3$ & $4 E+3$ & $1 E+3(c)$ \\
\hline$N p-237$ & $2 E+3$ & $2 E+3$ & $9 E+2(c)$ \\
\hline$P u-238$ & $3 E+5$ & $2 E+5$ & $1 E+5(c)$ \\
\hline$P u-239$ & $7 E+4$ & $7 E+4$ & $4 E+4(c)$ \\
\hline $\mathrm{Pu}-240$ & $7 E+4$ & $7 E+4$ & $9 E+4$ \\
\hline Pu-241 & $7 E+5$ & $1 E+6$ & $\mathrm{LE}+8$ \\
\hline$P u-242$ & $8 E+4$ & $8 E+4$ & $3 E+4(c)$ \\
\hline$A m-24.1$ & $2 E+4$ & $4 E+4$ & $4 E+6$ \\
\hline
\end{tabular}

1980 ARCL Values ( $\mathrm{pCi} / \mathrm{g}$ ) Resulting in

in $500 \mathrm{mrem} /$ year at Indicated Times (a)

$100 \mathrm{yrs} \quad 400 \mathrm{yrs} \quad 10,000 \mathrm{yrs}$

$1 \mathrm{E}+12$

$4 \mathrm{E}+4$

$2 E+4(c)$

$\because$

$r-90$

$2 E+3(c)$

$8 \mathrm{E}+8$

$5 \mathrm{E}+1$

$1 E+7$

$8 E+0$

$2 \mathrm{E}+2$

Th-230

TE+

$4 E+1$

$3 E+0(c)$

$4 \mathrm{E}+2(\mathrm{C})$

$2 E+3(c)$

$4 E+1(c)$

$6 \mathrm{E}+2(\mathrm{c})$

$1-235$

$4 E+3$

$3 E+3$

$1 \mathrm{E}+3(\mathrm{c})$

U 238

$4 E+3$

$4 E+3$

$9 E+2(c)$

$1 E+5(c)$

$4 E+4(C)$

$9 \mathrm{E}+4$

$\mathrm{LE}+8$

$4 E+6$

(a) All values have been rounded to one significant figure.

(b) Dashes (--) indicate concentrations are indicated greater than the specific activity of the pure substance.

(c) Indicates nuclides for which the ARCL is controlled by events at long time periods. 
TABLE 4.6 Results of Equation 3 for Site 218-W-4B

(Trenches Only)

Sum of the Ratios of Existing Concentration to ARCL $\left(\Sigma \rho_{j} / P_{j}\right)$ for three Design Objectives

With TRU

\begin{tabular}{|c|c|c|}
\hline $25 \mathrm{mrem} / \mathrm{yr}$ & $100 \mathrm{mrem} / \mathrm{yr}$ & $500 \mathrm{mrem} / \mathrm{yr}$ \\
\hline 240 & 61 & 12 \\
\hline 40 & 20 & 2 \\
\hline
\end{tabular}

Wi thout TRU

$\begin{array}{lrrr}\text { Year } 100 & 210 & 53 & 11 \\ \text { Year } 400 & 15 & 4 & 0.9\end{array}$

The values in Table 4.6 are calculated using the most restrictive of the 100 and 10,000 year values in Table 4.4 for the "year 100" row, and the most restrictive of the Table 4.4 values for years 400 and 10,000 for the "year 400" row. The "year 100" row shows the need for some action for both geologic and in-situ disposal. The "year 400" row indicates the need for long-term barriers unless the TRU trench is removed for all design objectives. Short-term barriers are indicated for in-situ disposal in all cases.

It is interesting to note that the contamination levels of Table 4.3, if left as they are now, could result in a dose rate of up to 5.4 rem/year in 100 years, declining to $0.45 \mathrm{rem} /$ year in 400 years, based on the assumed exposure scenario. (This information can he derived from Tables 4.3 and 4.4.) Following removal of the TRU trench, any barrier that would prevent farming for 400 years would result in this site meeting the $500 \mathrm{mrem} / \mathrm{year}$ design objective for in-situ disposal. Any barrier that resulted in a 75 percent reduction in exposure for long periods, as could be obtained by a $1.2 \mathrm{~m}(3.9 \mathrm{ft})$ layer of soil or a $0.8 \mathrm{~m}(2.6 \mathrm{ft})$ layer of rocks, would result in the site meeting a $100 \mathrm{mrem} / \mathrm{year}$ design objective. Meeting the $500 \mathrm{mrem} /$ year objective in the year 100 through waste recovery would require removal of over 91 percent of the wastes in the site. 


\subsubsection{Simplification for Similar Hanford Sites}

The radionuclides dominating the dose analysis of example site 218-W-4B in Section 4.2.2 are strontium-90 and plutonium-239. For the case where the TRU storage trench is removed, the dominant radionuclides are strontium-90 and cesium-137. Analysis of many waste sites at Hanford has shown that the significant pathways and radionuclides are similar for a large variety of sites. The doses are dominated for the first several hundred years by strontium-90, cesium-137, and various isotopes of plutonium, and afterwards by the various long-lived transuranics. This is a result of common waste sources at Hanford, the defense related reprocessing activities. Since this is a general conclusion, it is possible to develop a shortened procedure for waste sites at Hanford for which the scenario described in Section 4.2.1 applies.

The "Site Characterization and Inventory of Hanford Defense Waste" (Rockwel1 1982) contains 1ists of projected Hanford radionuclide inventories. These show that, for the next hundred years, Sr-90 and Cs-137 will account for about $94 \%$ of all the fission product activity at Hanford, and isotopes of plutonium and americium account for $95 \%$ of the remainder. Out to 10,000 years, plutonium still accounts for over $90 \%$ of the actinide activity, while Tc-99 becomes $67 \%$ of the total fission product inventory remaining.

It is possible to derive a generalized unmodified maximum annual dose and an ARCL for a mixture of radionuclides, assuming the mixture is known. This can be done from base principles for any scenario. It may also be done by back-calculating from site-specific ARCL, such as those given in Table 4.5, as

$$
\text { UMADmixture }=\frac{D 0\left[\sum_{i} \rho_{j} / P_{i} \pi_{j} M_{j}\right]}{\sum_{k} \rho_{k}}
$$


This is a simple modification of Equations 2 and 3 given in Section 2.2.3, and all variables are defined as before.

From Rockwell 1982, Appendix A, a spectrum of radionuclides at the subject times $c$ an be derived. This is given in abbreviated form in Table 4.7. It is apparent from Table 4.8 that along with Cs-137, Sr-90, and their daughters, only five other isotopes make up nearly $99.5 \%$ of the in-tank radioactivity at 100 years decay. These nuclides still account for over $70 \%$ of the activity 10,000 years hence. Thus, it seems reasonable to prepare a Hanford-specific UMAD, based on the scenario of Section 4.2.1, for a mixture of the isotopes Tc-99, Sm-151, Pu-239, Pu-240, and Am-241. This may be used with the UMAD for Cs-137 and Sr-90 to do simple screening of Hanford-related waste sites. This UMAD, calculated using Equation 6, is $1 \times 10^{+4}$ at 100 years, $1 \times 10^{+4}$ at 400 years, and $6 \times 10^{+3} \mathrm{mrem} /$ year per total $\mu \mathrm{Ci} / \mathrm{g}$ at 10,000 years.

TABLE 4.7 Hanford Radionuclide Inventories of In-Tank Defense Waste as a Function of Time (From Rockwell 1982, Appendix A)

\begin{tabular}{|c|c|c|c|}
\hline \multirow[b]{2}{*}{ Nuclide } & \multicolumn{3}{|c|}{ Radionuclide Inventory at Selected Times, C } \\
\hline & 100 Years & 400 Years & 10,000 Years \\
\hline Sr-90 & $5.4 \mathrm{E}+6$ & $4.9 E+3$ & $0.0 \mathrm{EO}$ \\
\hline Tc-99 & $3.8 E+4$ & $3.8 E+4$ & $3.6 E+4$ \\
\hline Cs -137 & $2.3 E+6$ & $2.9 E+3$ & $0.0 \mathrm{EO}$ \\
\hline Sm-151 & $7.2 E+5$ & $7.5 E+4$ & $0.0 E 0$ \\
\hline Pu-239 & $2.4 \mathrm{E}+4$ & $2.4 E+4$ & $1.8 E+4$ \\
\hline$P u-240$ & $6.6 E+3$ & $6.4 \mathrm{E}+3$ & $2.4 E+3$ \\
\hline Am-241 & $1.5 E+5$ & $9.3 E+4$ & $5.4 E-1$ \\
\hline A11 Others $(a)$ & $5.2 E+4$ & $1.6 E+4$ & $2.4 E+5$ \\
\hline
\end{tabular}

(a) Excluding Sr-90 and Cs-137 daughters $Y-90$ and $\mathrm{Ba}-137 \mathrm{~m}$. 


\subsection{CDMPARISON OF ARCL RESULTS WITH OTHER RECOMMENDATIONS}

As discussed in Section 1.1, various researchers and regulatory agencies have proposed soil concentration limits for selected circumstances. The results of the examples given in Section 4 can be compared with suggested values for both surface and subsurface contamination.

\subsection{SURFACE CONTAMINATION}

Numerous researchers have studied the problem of radiation dose to individuals from residual soil contamination. The results have been couched in various terms (maximum permissible concentration levels, resulting doses, and others) for various purposes. For comparison the results of three of the most comprehensive studies are listed in Table 5.1 along with the results of the ARCL method. The basis of the comparison is the soil concentration of each radionuclide that results in a $500 \mathrm{mrem} / \mathrm{yr}$ dose to an individual. The values from Boothe (1979) are for a Hanford-specific scenario, assuming institutional control continues indefinitely. Because there is no possibility for an onsite resident in Boothe's assumptions, his results are generally higher than the others. The exceptions are uranium and plutonium. Boothe applies the limits air and water concentration of DOE Manual Chapter 0524 and an inhalation resuspension factor much greater than those generally used, rather than a dose limit. The range of results given by Healy, Rodgers, and Wienke (1979) are for two scenarios, one with a diet consisting of entirely home-grown foods, the other with only limited consumption of home-grown food. These results fit relatively closely with those derived from a study of nuclear waste burial grounds by Murphy and Holter (1980). The values from Murphy and Holter are derived from the inventory and resulting doses presented in the appendices of the burial ground study, corrected for decay. Finally, the ARCL values given are derived from Table 4.2, corrected for radioactive decay to match the other scenarios. All ARCL values are well within an order of magnitude of those by Healy, Rodgers, and Wienke (1979) and Murphy and Holter (1980), except the value for $s r-90$. 
TABLE 5.1 Contamination Levels that Result in Individual Annual noses of $500 \mathrm{mrem} /$ year to Bone Derived from Various References

\begin{tabular}{|c|c|c|c|c|}
\hline \multirow[b]{2}{*}{ Radionuclide } & \multicolumn{4}{|c|}{ Calculated Soil Contamination Levels, pCi/gram } \\
\hline & Boothe 1979 & Healy et al.1979 & Murphy 1930 & ARCL \\
\hline$S r-90$ & 400 & $20-100$ & 20 & 5 \\
\hline Cs-137 & 400 & $1-50$ & 180 & 190 \\
\hline$U-238$ & 300 & $8-50(a)$ & $400(a)$ & $5-9001$ \\
\hline Pu-239 & 60 & $100-50 n 0(b)$ & 850 & 520 \\
\hline
\end{tabular}

(a) Highly dependent on daughter product accumulation.

(b) From Healy 1977

The difference for strontium is the use of a Hanford site-specific, plantto-soil concentration ratio for the ARCL calculation that is an order of magnitude greater than that conventionally used for generic analyses.

The comparison of results in Table 5.1 illustrates two things. First, consideration of site-specific exposure parameters can result in significant differences in the final result--as illustrated by the differences in the results of Boothe and the others. Second, that even though assumptions and methods may vary widely, for similar situations different studies will get similar results, as shown in the correspondences of Healy, Rodgers, and Wienke with the ARCL and Murphy and Holter.

\subsection{SUBSURFACE CONTAMINATION}

The most complete study of potential individual doses from residual radionuclides was recently issued by the NRC (1981a). NRC defined radioactive waste classes for disposal in solid waste burial grounds. The most restrictive class (Class $C$ ) is defined on the basis of an intruderagriculture scenario for a burial ground. Dther assumptions are that the wastes are beneath a 5-meter thick layer of clean overburden, and have aged 500 years.

The proposed NRC standard and corresponding ARCL result for several radionuclides are given in Table 5.2. For most radionuclides, the 
TABLE 5.2 Comparison of 10 CFR Part 51 Disposal Concentration Values with Site-Specific Calculations for Hanford

\begin{tabular}{|c|c|c|c|}
\hline \multirow[b]{2}{*}{ Radionuclide } & \multicolumn{2}{|c|}{$\begin{array}{l}\text { Allowed Waste Concentrations } \\
\left(\mu \mathrm{C} i / \mathrm{cm}^{3}\right)\end{array}$} & \multirow[b]{2}{*}{ Ratio (b) } \\
\hline & 10 CFR $61(a)$ & ARCL Method & \\
\hline$T_{\frac{1}{2}}<5$ years & $\ldots(c)$ & -- & 1 \\
\hline$H-3$ & -- & -- & 1 \\
\hline $\mathrm{Ni}-59$ & 2.2 & 2.1 & 1 \\
\hline Sr-90 & 700 & 2,000 & 3 \\
\hline TC-99 & 0.3 & 0.3 & 1 \\
\hline I -129 & 0.008 & 0.003 & 0.4 \\
\hline$C s-135$ & 84 & 10 & 0.1 \\
\hline Cs-137 & 4,600 & 64,000 & 14 \\
\hline $\mathrm{U}-238$ & 0.05 & 0.2 & 4 \\
\hline$A m-241$ & $10 \mathrm{nCi} / \mathrm{g}$ & $1,200 \mathrm{nCi} / \mathrm{g}$ & 120 \\
\hline$P u-239$ & $10 \mathrm{nCi} / \mathrm{g}$ & $2,200 \mathrm{nCi} / \mathrm{g}$ & 220 \\
\hline
\end{tabular}

(a) Values from Table 1 Column 3) of 10 CFR Part 61 (Federal Register 1981).

(b) ARCL method results divided by 10 CFR 61 results.

(c) Theoretical specific activity.

correspondence is remarkably good. The value for Cs-137 by the IIRC includes a reduction because of possible intrusion directly into the waste, with attendant direct irradiation. The other major difference is for plutonium. The NRC limits are for non-TRU waste, which by arbitrary definition is set as waste containing less than $10 \mathrm{nCi} / \mathrm{g}$ of TRU isotopes. As can be seen from the dose-related ARCL, use of an arbitrary cutoff for any radionuclide could result in overly conservative standards being set, with resulting operational cleanup or disposal costs going up dramatically.

\subsection{DRAFT EPA CRITERIA}

The most recent draft proposals by the Environmental Protection Agency on standards for high-level waste disposal (Draft 40 CFR 191) contain two sections: the general criteria, which establish qualitative guidance for 
disposal programs, and the perfomance standards, which establish numerical limits on potential releases. The general criteria apparently apply to the design of any disposal system, yet the perfomance standards are developed for a specific kind of deep geologic waste repository.

The ARCL method described here is in congruence with all seven recommendations of the EPA general criteria. These recommendations are:

1) "Wastes should be disposed of promptly once disposal systems which comply with these standards are developed."

2) "Disposal systems should he designed to keep releases to the accessible environment as small as reasonably achievable, taking into account technical, social, and economic considerations."

3) "Disposal systems should use several different types of barriers to isolate wastes from the accessible environment. Both engineered and natural barriers shall be included. Each such barrier shall be separately designed to provide substantial isolation, regardless of the performance of other barriers."

4) "Active institutional controls should not be relied upon to isolate the wastes for more than 100 years after disposal."

5) "Disposal systems should be identified by the most permanent markers and records practicable to indicate the dangers of the wastes and their location."

6) "Disposal systems should not be located where there has been mining for resources or where there is a reasonable expectation of exploration for scarce or easily accessible resources in the future. Further, disposal systems should not be located where there is a significant concentration of any material which is not widely available from other sources."

7) "Disposal systems should be designed so that most of the wastes may be recovered if this is found necessary in the future, unless the wastes are removed from the Earth." 
None of these general recommendations conflict with the concept of 1 imiting annual radiation dose to an individual through site-specific analyses. In fact, most of them would apply to the ARCL method with no changes in wording.

However, the basic standard proposed by the EPA based on the seven recommendations is at variance with the ARCL concept. The EPA has developed a set of radionuclide release limits, based on an analysis of a generic repository, that are designed to limit the number of "health effects" over a 10,000-year period. These are related to the total curie content of 1000 metric tons of heavy metal (MTHM). There are two difficulties with this approach as applied to existing areas of radioactive contamination. One is simply procedural, the second is philosophical.

The procedural problem with determining compliance of existing waste sites with the EPA release guides arises because the release 1 imits are based upon a specific quantity of "heavy metal" processed. For waste sites with contents only indirectly tied to reprocessing activities, it may be very difficult to determine the MTHM equivalent associated with the wastes. For defense-related reprocessing wastes, this is also the case, and may al so be undesirable from a national security standpoint.

The philosophical problem lies in the variance between release 1 imits and dose limits. The EPA rejected individual dose limits, the traditional form of radiation protection standard (10 CFR 10, 40 CFR 190), because long-lived radionuclides may persist in the environment and expose many individuals to small doses, resulting in larger cumulative effects. The "health effect" concept of EPA is in essence a control of the total population exposure. The ARCL method, conversely, is based on limiting doses to individuals. Radioactive wastes contained in isolated sites will have little potential for exposing more than a few people at any time. It is extremely unlikely that more than onsite individuals could be significantly exposed. Therefore, by limiting the individual dose, the population dose is minimized, and the individual members of the population are protected as well. 


\subsection{POTENTIAL USES OF THE ARCL METHOD}

The method for determining allowable residual contamination levels (ARCL) described in this report has several potential immediate applications. The method can help answer the general question "How clean is clean enough?" for a number of applications. There are a large number of $1 \mathrm{ow}-$ level, transuranic, and high-level waste storage and disposal areas on DOE nuclear facilities at various locations around the nation. The ARCL method could be used in the preparation of Environmental Impact Statements for disposal operations at many of these sites. Additionally, the Uranium Mill Tailings Remedial Action Program (UMTRAP), the Formerly Utilized Sites Remedial Action Program (FUSRAP), and the Grand Junction, Colorado, cleanup program are all under way. Objectives of these programs are to conduct radiological screening and engineering assessments at designated waste sites, to determine remedial action requirements, develop plans and specifications for implementing remedial actions, perform the necessary actions, and certify that sites can be released for unrestricted use (DOE 1981, Leggett, et al. 1981). The ARCL method is flexible enough to be adaptable to each of these programs, and could be used to develop regulatory baselines for other remedial action projects. 


\subsection{REFERENCES}

Anspaugh, L. R., et a1. 1974. "Experimental Studies on the Resuspension of Plutonium from Aged Sources at the Nevada Test Site." AtmosphereSurface Exchanges of Particulate and Gaseous Pollutants, pp. 727-732, CONF-740921.

Barnes, M. G. 1978. Statistical Design and Analysis in the Cleanup of Environmental Radionuclide Contamination. NV0 1253-12. Desert Research Institute. Las Vegas, Nevada

Boothe, G. F. 1979. Surface Soil Contamination Standards. RH0-CD-782. Rockwell Hanford Operations, Richland, Washington.

Bustad, L. K. and J. L. Terry. 1956. Basic Anatomical, Dietary and Physiological Data for Radiological Calculations. HW-41638, Hanford Atomic Products Operation, Richland, Washington.

Chapin, J. A. 1980. Pathways and Cost-Benefit Analyses for INEL Radioactively Contaminated Soil Areas Being Evaluated for Decontamination and Decommissioning. EGG-2041, Idaho National Engineering Laboratory, Idaho Falls, Idaho.

Clements, W. E., S. Barr and M. L. Marple. 1978. Uranium Mill Tailings Piles as Sources of Atmospheric 222Rn. LA-UR-78-828, Los Alamos Scientific Laboratory, Los Alamos, New Mexico.

Cline, J. F. 1979. Biobarriers Used in Shallow-Burial Ground Stabilization. PNL-2918. Pacific Northwest Laboratory. Richland, Washington.

Cline, J. F., K. A. Gano, and L. E. Rogers. 1980. "Loose Rock as Biobarriers in Shallow-Land Burial." Health Physics, 39:497-504.

Donovan, R. P., R. M. Felder, and H. H. Rodgers. 1976. Vegetative Stabilization of Mineral Waste Heaps, EPA-600/2-76-087. Research Triangle Park, North Carolina.

Duguid, J. 0. ORNL Burial Ground Investigations and Corrective Measures. Oak Ridge National Laboratory, Oak Ridge, Tennessee.

Eckerman, K. F. and M. W. Young. 1980. A Methodology for Calculating Residual Radioactivity Levels Following Decommissioning. NUREG-0707. U.S. Nuclear Regulatory Commission, Washington, D.C. 
Essig, T. H. and J. P. Corley. 1969. Criteria Used to Estimate Radiation Doses Received by Persons Living in the Vicinity of Hanford: Interim Report No. 2. BNLL-1019, Pacific Northwest Laboratory, Richland, Washington.

Federal Register, Vo1. 46, No. 27. 1981a. "Nuclear Regulatory Commission, 10 CFR Parts $30,40,50,70$ and 72, Decommissioning Criteria for Nuclear Facilities; Notice of Availability of Draft Environmental Impact. Statement." Washington, D.C.

Federal Register, Vol. 46, No. 142. 1981b. "Nuclear Regulatory Commission 10 CFR Parts 2, 19, 20,21, 30, 40, 51,61, 70 73, and 70: Licensing Requirements for Land Disposal of Radioactive Waste." Washington, D.C.

Hawkins, R. H. and J. H. Horton. 1967. "Bentonite as a Protective Cover for Buried Radioactive Haste." Health Physics 13:287-292.

Hayden, J. A., et a1. 1980. Soil Decontamination Criteria Report, November 1980. RFP-31620, Rockwell International, Rocky Flats Plant, Golden, Colorado.

Healy, J. W., and W. J. Wenzel. 1976. Contamination Limits for Real and Persona1 Property, Progress Report for January-June 1976. LA-6484-PR, Los Alamos Scientific Laboratory, Los Alamos, New Mexico.

Healy, J. W. 1977. An Examination of the Pathways from Soil to Man for Plutonium. LA-6741-MS, Los Alamos Scientific Laboratory, Los Alamos, New Mexico.

Healy, J. W., and J. C. Rodgers. 1978. A Preliminary Study of Radium Contaminated Soils. LA-7391-MS, Los Alamos Scientific Laboratory, Los Alamos, New Mexico.

Healy, J. W., J. C. Rodgers and C. L. Wienke. 1979. Interim Soil Limits for D\&D Projects. LA-UR-79-1865-Rev., LOS Alamos Scientific Laboratory, Los Alamos, New Mexico.

Hi11, G. S. 1979. Doses for Various Pathways to Man Based on Unit Concentrations of Radionuclides Pertinent to Decontamination and Decommissioning of Properties. ORNL/OEPA-7, Oak Ridge National Laboratory, Oak Ridge, Tennessee.

Holcomb, H. P. 1979. "Radionuclide Content of an Exhumed Canyon Tank and Neighboring Soil." Management of Low-Level Radioactive Waste, Vol. 2. Pergamon Press. New York, New York. 
Horton, J. H. 1979. "Exhumation Test with Aged Radioactive Solid Wastes." Management of Low-Level Radioactive Waste, Vol. 2. Pergamon Press. New York, New York.

Houston, J. R., D. L. Strenge, and E. C. Watson. 1974. DACRIN--A Computer Program for Calculating Organ Doses from Acute or Chronic Radionuclide Inhalation, BNWL-B-389. Pacific Northwest Laboratory, Richland, Washington.

Hughes, J. 1975. Use of Bentonite as a Soil Sealant for Leachate Control in Sanitary Landfills. V.0.L. Soil Laboratory Engineering Report 280-E, American Colloid Company. Skokie, Illinois.

Isaacson, R. E., and D. J. Brown. 1978. Environmental Assessment Related to Hanford Radioactive Waste Burial, RHO-SA-36. Rockwell Hanford Operations, Richland, Washington.

Kennedy, W. E., Jr., E. C. Watson, G. R. Hoenes, and B. A. Napier. 1979. A Method For Determining Acceptable Residual Radioactive Contamination Levels, PNL-SA-7495. Presented at the 24th Annual Meeting of the Health Physics Society. Philadelphia, Pennsylvania.

Last, G. V., and D. W. Duncan. 1980. Radionuclide Distributions in Soils of the U-Pond Disposal System, RHO-CD-1119. Rockwell Hanford Operations, Richland, Washington.

Leggett, R. W., et al. 1981. Radiological Surveys of Properties in the Middlesex, New Jersey, Area, D0E/EV-0005/1, Oak Ridge National Laboratory, Oak Ridge, Tennessee.

Lienhart, D. A., and T. E. Stransky. 1981. "Evaluation of Potential Sources of Riprap and Armor Stone - Methods and Considerations," Bul1. Ass. Eng. Geol., 18(3), pp. 323-332.

Macbeth, P., et a1. 1979. Evaluation of Alternative Methods for the Disposal of Low-Level Radioactive Wastes, NUREG/CR-0680. Ford, Bacon, and Davis, Salt Lake City, Utah.

Mckenzie, D. H., L. L. Cadwel1, C. E. Cushing, Jr., R. Harty, W. E. Kennedy, Jr., M. A. Simmons, J. K. Soldat, and G. Swartzman. 1982. Relevance of Bintic Pathways to the Long-Term Pegulation of Nuclear Haste Disposal: A Report on Tasks 1 and 2. NIUREG/CR-2675, PNL-4241, Pacific Northwest Laboratory, Pichland, Washington.

Merrick, D. L. 1981. "Pevised Sample Data Package for Example Site." Rockwel1 Letter 81-0835. Rockwe11 Hanford Operations, Richland, Washington. 
Mishima, J. to C. E. Jenkins, memo dated 9/22/80. "Guidance for Preconceptual Engineering Criteria to Mitigate Erosion, Biological Intrusion, and Water Penetration of Buried Waste." Pacific Northwest Laboratory, Richland, Washington.

Mueller, M. A., W. E. Kennedy, Jr., and J. K. Soldat. 1981. Review of Soil Contamination Guidance, PNL-3866. Pacific Northwest Laboratory, Richland, Washington.

Murphy, E. S., and G. M. Holter. 1980. Technology, Safety and Costs of Decommissioning a Reference Low-Level Waste Burial Ground, NUREG/CR-0570. Pacific Northwest Laboratory, Richland, Washington.

Napier, B. A., G. R. Hoenes, W. E. Kennedy, Jr., and E. C. Watson. 1979. The Maximum Annual Dose Resulting From Residual Radioactive Contamination, PNL-SA-7496. Presented at the 24th Annual Meeting of the Health Physics Society. Philadelphia, Pennsylvania.

Napier, B. A., W. E. Kennedy, Jr., and J. K. Soldat. 1980a. PABLM - A Computer Program to Calculate Accumulated Radiation Dose from Radionuclides in the Environment. PNL-3209, Pacific Northwest Laboratory, Richland, Washington.

Napier, B. A., R. L. Roswell, W. E. Kennedy, Jr., and D. L. Strenge. 1980b. ARRRG and FOOD--Computer Programs for Calculating Radiation Dose to Man from Radionuclides in the Environment, PNL-3180, Pacific Northwest Laboratory, Rich1and, Washington.

Napier, B. A. 1981. Standardized Input for Hanford Environmental Impact Statements, PNL-3509, Pacific Northwest Laboratory, Richland, Washington.

National Academy of Sciences Panel on Hanford Wastes. 1978. Radioactive Wastes at the Hanford Reservation--A Technical Review. Washington, D.C.

Oak, H. D., G. M. Holter, W. E. Kennedy, Jr., and G. J. Konzek. 1980 Technology, Safety and Costs of Decommissioning a Reference Boiling Water Peactor Power Station. NUREG/CR-0672, Vol. 2, Appendix F, pp. F.11-F.15. Prepared for the U.S. Nuclear Regulatory Commission by Pacific Northwest Laboratory, Richland, Washington.

Rockwell Hanford Operations. 1980. Technical Aspects of Long-Term Management Alternatives for High-Level Defense Waste at the Hanford Site, RHOLD-141. Richland, Washington.

Rockwell Hanford Operations. 1982. Site Characterization and Inventory of Hanford Defense Waste, RHO-HS-ST-1, Richland, Washington.

Schiager, K. J. 1977. Radwaste Radium-Radon Risk. Graduate School of Public Health, Pittsburgh, Pennsylvania. 
Strenge, D. L. 1975. DACRIN--A Computer Program for Calculating Organ Doses From Acute or Chronic Radionuclide Inhalation: Modification for Gastroincestinal Tract uose, bNwL-b-joy Supp., raciric Nortnwest Laboratory, Richland, Washington.

Sunset Editorial Staff. 1959. Sunset Western Garden Book. Lane Publishing Co., Menlo Park, California.

Tubbs, D. W. 1979. Pacific Northwest Geomorphology and Hydrology: Rates and Probabilities of Selected Processes and Events, Consultant Input, PNL-2851, Pacific Northwest Laboratory, Richland, Washington.

U.S. Atomic Energy Commission. 1973. Radioactive Waste Management, AEC Manual Chapter 0511. Washington, D.C.

U.S. Atomic Energy Commission. 1974. Termination of Operating Licenses for Nuclear Reactors. Regulatory Guide 1.86, Directorate of Regulatory Standards, Washington, D.C.

10 CFR 20.105. 1980. U.S. Code of Federal Regulations. Title 10, Part 20.105, "Permissible Levels of Radiation in Unrestricted Areas." Government Printing Office, Washington, D.C.

10 CFR 140.84. 1980. U.S. Code of Federal Regulations. Title 10, Part 140.84, "Criterion I - Substantial Release of Radioactive Material or Substantial Radiation Levels Offsite." Government Printing Office, Washington, D.C.

40 CFR 190. 1980. U.S. Code of Federal Regulations. Title 40, Part 190, "Environmental Protection Standards for Nuclear Power Operations." Government Printing Office, Washington, D.C.

40 CFR 192. 1980. U.S. Code of Federal Regulations. Title 40, Part 192, "Environmental Protection Standards for Uranium Mill Tailings," Government Printing Office, Washington, D.C.

U.S. Department of Agriculture. 1951. Soil Survey Manual, Handbook No. 18, Washington, D.C.

U.S. Department of Energy. 1980b. Management of Commercially Generated Radioactive Waste, DOE/EIS-0046F, Washington, D.C.

U.S. Department of Energy. 1981. Background Report for the Uranium Mill Tailings Remedial Action Program, DOE/EP-0011, Washington, D.C.

U.S. Energy Research and Development Administration. 1975. Waste Management Operations: Hanford Reservation. ERDA-1538, Washington, D.C. 
U.S. Environmental Protection Agency. 1977. Proposed Guidance on Dose Limits for Persons Exposed to Transuranium Elements in the General Environment, Summary Report. 520/4-77-016, Washington, D.C.

U.S. Environmental Protection Agency. 1978. Study of Engineering and Water Management Practices that will Minimize the Infiltration of Precipitation into Trenches Containing Radioactive Waste, ORP LV-78-5, Washington, D.C.

U.S. Nuclear Regulatory Commission. 1981a. Draft Environmental Impact Statement on 10 CFR Part 61, "Licensing Requirements for Land Disposal of Radioactive Waste." NUREG-0782, Vols. 1 through 4, U.S. Nuclear Regulatory Commission, Washington, D.C.

U.S. Nuclear Regulatory Commission. 1981. Draft Generic Environmental Impact Statement on Decommissioning of Nuclear Facilities. NUREG-0586, U.S. Nuclear Regulatory Commission, Washington, D.C.

Wallace, R. W., et al. 1980. Topical Report on Release Scenario Analysis of Long-Term Management of High-Level Defense Waste at the Hanford Site, PNL-3363, Pacific Northwest Laboratory, Richland, Washington.

Washington State University. 1970. Alfalfa Irrigation, E.M 3468. Cooperative Extension Service, Pullman, Washington.

Watson, E. C., memo to distribution dated 12/26/80. "Hanford Defense Waste Disposition Criteria." Pacific Northwest Laboratory, Richland, Washington.

Wheeler, and W. J. Smith II. 1979. "Considerations for the Long Term: Perpetual is Not Forever," in Management of Low-Level Radioactive Waste, Vol. I, Pergamon Press, New York, New York.

Winkler, E. M. 1975. Stone: Properties, Durability in Man's Environment, Second Edition, Springer-Verlag, Wein, New York. 
No. of

Copies

OFFSITE

A. A. Churm

DOE Patent Division

9800 S. Cass Avenue

Argonne, IL 60439

27 DOE Technical Information Center

L. R. Anspaugh

Lawrence Livermore Laboratory

P.0. Box 808

Livermore, CA 94550

B. G. Bennet

Environmental Measurements Laboratory

U.S. Department of Energy

New York, NY 10014

H. S. Bennett

Transuranic Waste Systems Office Rockwel1 International

Rocky Flats Plant

Golden, CO 80401

G. D. Calkins

U.S. Nuclear Regulatory Commission Washington, D.C. 20555

R. P. Campbel 1

Sandia National Laboratory

P.0. Box 5800

Albuquerque, NM 87185
No. of

Copies

OFFSITE (contd)

J. A. Chapin

EG\&G Idaho

P.0. Box 1625

Idaho Falls, ID 83401

J. L. Crandal 1

Savannah Piver Laboratory

Aiken, SC 29801

P. Dickman

Reynolds Electric Engineering Co. Mercury, NV 89023

K. F. Eckerman

Oak Ridge National Laboratory

P.0. Box $X$

Oak Ridge, TN 37830

D. C. Fulmer

Savannah River Operations office

Department of Energy

Aiken, SC 29801

R. S. Garvin

Savannah River Laboratory

Aiken, SC 29801

J. W. Catrel1

Office of Nuclear Waste llanagement

Department of Energy

Washington, D.C. 20545 
No. of

Copies

OFFSITE (contd)

K. Gilbert

Transuranic Waste Systems Dffice

Rockwel 1 International

Rocky Flats Plant

Golden, C0 80401

J. W. Healy

Los Al amos National Laboratory

P.0. Box 1663

Los Alamos, NM 87545

T. B. Hindman, Jr.

Savannah River Operations Office

Department of Energy

Aiken, SC 29801

R. T. Huntoon

Savannah River Laboratory

Aiken, SC 29801

Lawrence Livermore Laboratory

Reference Library

P.0. Box 808

Livermore, CA 94550

G. Levin

EG\&G Idaho

P.0. Box 1625

Idaho Falls, ID 83401

E. B. Lewi s

National Academy of Science

Cal ifornia Institute of Technology

Pasadena, CA 91109

Los Alamos National Laboratory

Reference Library

P.0. Box 1663

Los Alamos, NM 81544
No. of

Conies

OFFSITE (contd)

R. S. Lowrie

Oak Ridge National Laboratory

P.0. Box $X$

Oak Ridge, Til 37830

R. Y. Lowrey

U.S. Department of Energy

P.0. Box 5400

Albuquerque, NN 87115

C. A. Little

Oak Ridae National Laboratory

P.0. Box $X$

Oak Ridge, TN 37830

D. D. T. Lynch

TMI Project Office

office of Nuclear Reactor

Regulation

U.S. Nuclear Regulatory Commission

Washington, D.C. 20555

E. F. Mastal

Office of Nuclear Waste llanagement Department of Energy

Washington, D.C. 20545

D. J. McGoff

Office of Nuclear Waste llanagement

Department of Energy

Washington, D.C. 20545

J. E. McLaughl in

Environmental Measurements Laboratory

Department of Energy

New York, NY 10014

Beverly Rawles

Battelle Memorial Institute office of Nuclear Waste Isolation 505 King Avenue

Columbus, $\mathrm{OH} 43201$ 
No. of

Copies

OFFSITE (contd)

Oak Ridge National Laboratory Central Research Laboratory Document Reference Section Oak Ridge, TN 37830

G. K. Oertel

Office of Nuclear Waste Management Department of Energy Washington, D.C. 20545

J. C. Rodgers

Los Alamos National Laboratory P.0. Box 1663

Los Alamos, NM 87545

Savannah River Laboratory

Reference Library

Aiken, SC 29801

T. Scott

Transuranic Waste Systems Office Rockwel 1 Internatonal

Rocky Flats Plant

Golden, CO 80401

A. Taboas

Office of Nuclear Waste Management Department of Energy

Washington, D.C. 20545

V. G. Trice

Office of Nuclear Waste Management

Department of Energy

Washington, D.C. 20545

E. J. Wahl quist

Office of Nuclear Waste Management Department of Energy

Washington, D.C. 20545
No. of

Copies

OFFSITE (contd)

R. Wal ton

Office of Nuclear Waste Management Department of Energy

Washington, D.C. 20545

R. L. Watters

Office of Nuclear Waste Management

Department of Energy

Washington, D.C. 20545

I. White

National Council on Radiation

Protection \& Measurements

785 Southeast Vista

Gresham, OR 97030

F. W. Wicker

Colorado State University

Fort Collins, CO 80523

\section{ONSITE}

9 DOE Richland Operations Office

H. E. Ransom

E. A. Bracken

R. M. Carosino

P. F. X. Dunigan, Jr.

R. B. Goranson

R. L. Hames

J. J. Schreiber

M. W. Shupe

F. R. Standerfer

UNC Industries

T. E. Dabrowski 
No. of

Copies

ONSITE (contd)

12 Rockwell Hanford Operations

G. F. Boothe

J. L. Deichman

M. W. Eidinger

G. D. Forehand

K. A. Gasper

A. P. Hawkins

R. L. Koontz

P. G. Lorenzini

D. L. Merrick

M. B. Walmsley

D. E. Wood

P. A. Ybarra

55 Pacific Northwest Laboratory

K. E. Byers (4)

M. G. Foley

G. R. Hoenes

B. H. Howes

C. E. Jenkins (3)

W. E. Kennedy, Jr. (2)

J. M. Latkovich

R. F. McCallum

W. D. McCormack

B. A. Napier (15)

I. C. Nel son

L. A. Nieves

J. V. Robinson (2)

D. J. Silviera

J. K. Soldat (2)

J. G. Stephan

S. L. Stein

L. A. Stout

S. L. Sutter

C. M. Unruh
No. of

Copies

ONSITE (contd)

B. E. Vaughan

R. W. Wallace

E. C. Watson

Publishing Coordination (2)

Technical Information (5) 